\title{
aSynthesis, thermal stability, vibrational spectra and conformational studies of novel dicationic meta-xylyl linked bis-1-methylimidazolium ionic liquids.
}

\author{
Mostefa Boumediene1, Boumediene Haddad 1,2,3, ${ }^{*}$, Annalisa Paolone ${ }^{4}$, Mokhtar Drai ${ }^{2,5}$, \\ Didier Villemin ${ }^{3}$, Mustapha Rahmouni ${ }^{2}$, Serge Bresson ${ }^{6}$, Ouissam Abbas ${ }^{6}$

\footnotetext{
${ }^{1}$ Department of Chemistry, Faculty of Sciences, Dr Moulay Tahar University of Saïda, Algeria

2 Synthesis and Catalysis Laboratory LSCT, Tiaret University, Tiaret, Algeria

${ }^{3}$ LCMT, ENSICAEN, UMR 6507 CNRS, University of Caen, 6 bd Ml Juin, 14050 Caen, France

${ }^{4}$ CNR-ISC, U.O.S. La Sapienza, Piazzale A. Moro 5, 00185 Roma, Italy

${ }^{5}$ Université Djillali Liabes, BP 89, 22000 Sidi-Bel-Abbes, Algeria

${ }^{6}$ Laboratoire de Physique des Systèmes Complexes, Université Picardie Jules Verne, 33 rue St Leu 80039 Amiens cedex, France.
}

\begin{abstract}
In recent years, dicationic ionic liquids have been subject of a strongly growing research effort for their interesting and important properties that suggest them to be potential candidate for many applications. Therefore, the knowledge about the synthesis, thermal stability, vibrational spectra and conformational behaviour of these compounds is an important subject of study. The objective of the work presented in this paper is to investigate the influence of the substituent relative meta-position of dicationic ionic liquids (ILS), namely meta-xylyl linked bis-1-methylimidazolium ILs, on thermal stability, vibrational spectra and conformational studies. In the first step, four new meta-xylyl linked bis-imidazolium [m$\left.\mathrm{C}_{6} \mathrm{H}_{4}\left(\mathrm{CH}_{2} \mathrm{ImMe}\right)_{2}{ }^{+}\right]$ionic liquid (ILs) containing the dichloride $\left[\mathrm{Cl}^{-}\right]_{2}$, di(bis(trifluoromethylsulfonyl) Imide) $\left[\left(\mathrm{CF}_{3} \mathrm{SO}_{2}\right)_{2} \mathrm{~N}^{-}\right]_{2}$, bis(tetrafluoroborate) $\left[\mathrm{BF}_{4}^{-}\right]_{2}$ and bis (hexafluorophosphate) $\left[\mathrm{PF}_{6}^{-}\right]_{2}$ anions were synthesized. The obtained dicationic ILs were characterized by ${ }^{1} \mathrm{H}-\mathrm{NMR},{ }^{13} \mathrm{C}-\mathrm{NMR},{ }^{19} \mathrm{~F}-\mathrm{NMR},{ }^{31} \mathrm{P}-\mathrm{NMR}$ and FT-IR spectroscopy. Also, their thermal properties were determined and compared. The thermal behavior confirmed that [m$\left.\mathrm{C}_{6} \mathrm{H}_{4}\left(\mathrm{CH}_{2} \mathrm{ImMe}\right)_{2}{ }^{+}\right]$dicationic ILs containing $\left[\left(\mathrm{CF}_{3} \mathrm{SO}_{2}\right)_{2} \mathrm{~N}^{-}\right]_{2}$ and $\left[\mathrm{PF}_{6}^{-}\right]_{2}$ are more stable that the dichloride $\left[\mathrm{Cl}^{-}\right]_{2}$, and bis(tetrafluoroborate) $\left[\mathrm{BF}_{4}^{-}\right]_{2}$ dicationic ILs, and they show a good thermal stability up to $340^{\circ} \mathrm{C}$ which makes them suitable for thermal application. In the next step, a computational study of the conformers of $\left[\mathrm{m}^{-} \mathrm{C}_{6} \mathrm{H}_{4}\left(\mathrm{CH}_{2} \mathrm{ImMe}\right)_{2}\right]$, by means of DFT calculations with the $6-31 \mathrm{G}^{* *}$ basis set and the B3LYP theory was performed. Additionally, vibrational spectroscopy studies were conducted by infrared (FTIR) and Raman (FT-Raman) spectroscopy on the four dicationic ILs, differing for their anions. Finally a computational investigation of the interactions between anions and cation is presented.
\end{abstract}

KEYWORDS: Meta-xylyl; bis-imidazolium; Thermal analysis; conformers; Raman measurements; DFT calculations.

${ }^{*}$ Corresponding author.

E-mail : haddadboumediene@yahoo.com 


\section{INTRODUCTION}

One of the principal aims of modern chemistry is to design effective solvents that will be alternative to organic solvents, and that would not have the same disadvantages (e.g: high toxicity, high flammability and high vapor pressure) [1-2].

Scientific researchers in this field have suggested several tracks for the discovery of a new class of solvents, less harmful and less volatile. One of them regards "ionic liquids", which have been developed in the last decade as new green solvents, more acceptable to the environment, with excellent physical and chemical properties [3] that make them green substitutes more attractive compared to conventional organic solvents. They exhibit several exciting properties, such as their low melting points [4], good solvation properties [5], their very low vaporization voltages [6], their thermal and chemical stabilities [7] and their high solubilities [8].

Concerning their structures, they are designable properties, determined by the molecular interactions between the ions [9]. Therefore, unravelling the structureproperty relationships and finding universal correlations that can be utilized for a rational design is one of the main aim of the current research; in other words the coupled selected cations - anions can be adapted and adjusted to obtained ionic liquids with physicochemical properties desired for a specific application [10]; among these adjustments, it is possible to functionalize the imidazole as precursor in the synthesis reactions for the production of new substituted ionic liquids with new properties [11].

Recently, a new class of the ionic liquid family known as dicationic ionic liquids (ILs) has emerged as more effective and versatile compared to conventional monocationic ILs. Dicationic ionic liquids based on imidazolium [12], pyrrolidinium [13], piperidinium [14], and ammonium [15] cations represent the majority of the investigations in this field. A comparison between dicationic ILs and monocationic ILs, having a different length of grafted alkyl group was reported.[16-17].

The dicationic ILs have been the subject of many experimental and theoretical studies because of their properties makes them attractive for applications in a variety 
of fields including organic synthesis, catalysis, electrochemistry, and separation. They are thermally more stable, with higher viscosities, melting point, densities [18$19]$, and have a greater $d$ - spacing of the crystal structure than the monocationic ones [18].

The recent years have seen a strongly growing research effort regarding the influence of substituents functionalized in ionic liquids on the physical and chemical properties. In general, substituents in ortho, meta or para-positions alter the conformations, equilibrium relationships, vibrational spectra, the molecular structure, interionic interactions and thermal properties of the substituted in functionalized ionic liquids.

Very recently, we have investigated the conformers of the cation and the anioncation hydrogen bonding in Para-xylyl linked bis-imidazolium ionic liquids by using IR and Raman spectroscopic studies with the help of DFT calculation [20-21].

The facile synthesis of the same dicationic ILs (bis-imidazolium group) followed by new substitution at the position meta for the cationic site can give rise to new dicationic ILs namely Meta-xylyl linked bis-imidazolium ionic liquids; however, to the best of our knowledge, the study of the thermal stability, vibrational spectra and conformational studies of these dicationic ILs are not covered yet by the literature.

In this study, four new dicationic ILs based on meta-xylyl linked bis-imidazolium pairing the dichloride, bis(hexafluorophosphate), bis(tetrafluoroborate) and di(bis (trifluoromethanesulfonyl) imide) anions were investigated by using spectroscopic and thermal analysis; the thermal stability of all these dicationic ILs and their decomposition process were investigated, with the aim to understand the relationship between the structure and properties.

\section{MATERIALS, AND METHODS}

The chemicals used in this study: 1-methyl-1H-imidazole (> 99\%), [1,3-bis (chloromethyl) benzene], a, $\alpha^{\prime}$-dichloro-m-xylene $(98 \%)$, potassium hexafluorophosphate ( $\geq 99 \%$ ), lithium bis (trifluoromethylsulfonyl) Imide (99\%), ammonium tetrafluoroborate (99.5 wt \%), were purchased from Aldrich and used as 
received. Diethyl ether and $\mathrm{N}, \mathrm{N}$-dimethylformamide were purchased from Fluka. Deionized $\mathrm{H}_{2} \mathrm{O}$ was obtained with a Millipore ion-exchange resin deionizer.

\subsection{General procedure for the synthesis of dicationic ILs}

The synthesis of 3,3'-dimethyl-1,1'-(1,3-phenylenedimethylene)-bis(1H-imidazolium) dichloride can be described as follows [22]. Briefly, The dicationic IL named [m$\left.\mathrm{C}_{6} \mathrm{H}_{4}\left(\mathrm{CH}_{2} \mathrm{ImMe}\right)^{+}{ }_{2}\right]\left[\mathrm{Cl}_{2}\right]_{2}$ was prepared under microwave irradiation, from the mixture : $4.26 \mathrm{~g}(4.13 \mathrm{ml}, 50 \mathrm{mmol})$ of 1 -methylimidazole and $2.27 \mathrm{~g}(10 \mathrm{mmol})$ of the $\mathrm{m}$-xylene dichloride in $\mathrm{N}, \mathrm{N}$-dimethylformamide $(3 \mathrm{ml})$ at $100{ }^{\circ} \mathrm{C}$ for $3 \mathrm{~min}$. The resulting mixture was washed three times upon addition of diethyl ether $(100 \mathrm{ml})$, and then dried in vacuo ( $<1 \mathrm{mbar}$ ) for $8 \mathrm{~h}$, to give a white hygroscopic solid compound in high yield $(\approx 96 \%)$.

Three other dicationic ILs were synthesized by means of metathesis reactions (anion exchange) of the dichloride salts with:

- $\left[\mathrm{K}^{+} \mathrm{PF}_{6}\right]$ (1.2g, $\left.6.5 \mathrm{mmol}\right)$ dissolved in $20 \mathrm{ml}$ of demineralized water to give [m$\left.\mathrm{C}_{6} \mathrm{H}_{4}\left(\mathrm{CH}_{2} \mathrm{ImMe}\right)^{+}{ }_{2}\right]\left[\mathrm{PF}_{6}\right]_{2}{ }_{2}$ after a separation process.

- $\left[\mathrm{Li}^{+}\left(\mathrm{CF}_{3} \mathrm{SO}_{2}\right)_{2} \mathrm{~N}^{-}\right](1.86 \mathrm{~g}, 6.5 \mathrm{mmol})$ to give $\left[\mathrm{m}-\mathrm{C}_{6} \mathrm{H}_{4}\left(\mathrm{CH}_{2} \mathrm{ImMe}\right)^{+}{ }_{2}\right]\left[\left(\mathrm{CF}_{3} \mathrm{SO}_{2}\right)_{2} \mathrm{~N}^{-}\right] 2$ following the same procedure.

- $\left[\mathrm{NH}_{4}{ }^{+} \mathrm{BF}_{4}{ }^{-}\right](0.68 \mathrm{~g}, 6.5 \mathrm{mmol})$ under microwave heating to give $\left[\mathrm{m}-\mathrm{C}_{6} \mathrm{H}_{4}\left(\mathrm{CH}_{2} \mathrm{lmMe}\right)\right.$ $\left.{ }^{+}\right]\left[\mathrm{BF}_{4}{ }^{-}\right] 2$

The summary of the synthesis reactions is depicted in the following Scheme 1 and Scheme 2:

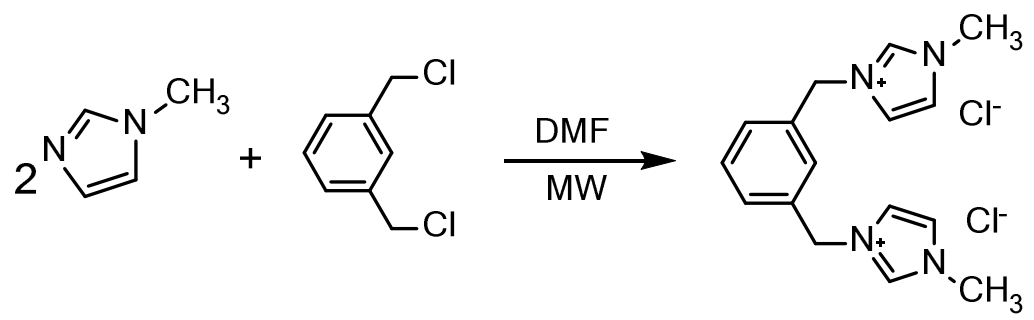

Scheme 1. Synthetic route of dichloride salt $\left[m-\mathrm{C}_{6} \mathrm{H}_{4}\left(\mathrm{CH}_{2} \mathrm{ImMe}\right)_{2}\right] \mathrm{Cl}_{2}, \mathrm{MW}$ microwave. 


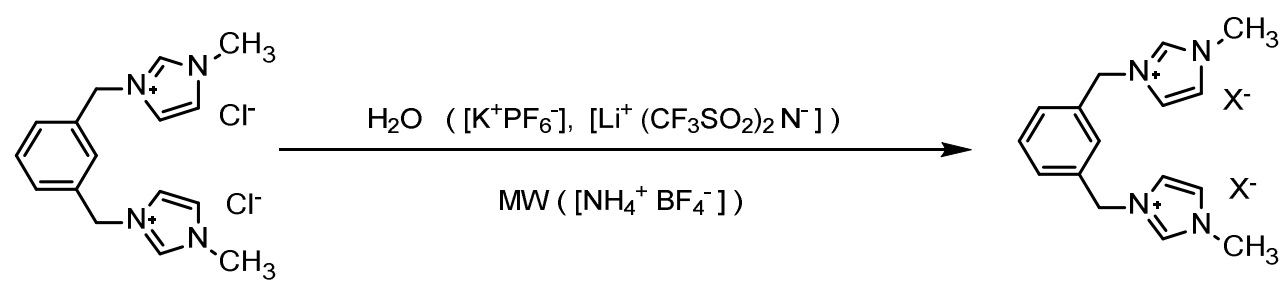

Scheme2.Metathesis reactions of [m- $\left.\mathrm{C}_{6} \mathrm{H}_{4}\left(\mathrm{CH}_{2} \mathrm{mme}\right)_{2}\right] \mathrm{X}_{2}$ from dichloride dicationic $\mathrm{IL}$, (with $\mathrm{X}=\left[\mathrm{PF}_{6}\right],\left[\left(\mathrm{CF}_{3} \mathrm{SO}_{2}\right)_{2} \mathrm{~N}\right]$ and $\left.\left[\mathrm{BF}_{4}\right]\right)$.

\subsection{NMR characterization}

The structures of synthesized dicationic ILs are confirmed by using ${ }^{1} \mathrm{H},{ }^{13} \mathrm{C},{ }^{19} \mathrm{~F}$ and ${ }^{31} \mathrm{P}$-NMR spectroscopy, in order to check the occurrence of the expected chemical reactions and confirm the absence of any impurities. ${ }^{1} \mathrm{H}-\mathrm{NMR}(500 \mathrm{MHz}),{ }^{13} \mathrm{C}-\mathrm{NMR}$ $(125.75 \mathrm{MHz})$ and ${ }^{19} \mathrm{~F}-\mathrm{NMR}(470.62 \mathrm{MHz})$ spectra were recorded on a Bruker DRX $500 \mathrm{MHz}$ spectrometer. Spectra were recorded in dimethylsulfoxide (DMSO-d 6 ), using the DMSO residual peak as the ${ }^{1} \mathrm{H}$ internal reference $(\delta=2.5$ and 3.3$)$, and the central peak of DMSO-d $\mathbf{d}_{6}$ at $\delta=39.5$ as the ${ }^{13} \mathrm{C}$ reference. Chemical shifts $(\delta)$ are given in ppm and referred to the internal solvent signal, namely TMS and $\mathrm{CFCl}_{3}$, respectively. All NMR spectra confirm that our dicationic ILs have been successfully synthesized and prove a good purity. The spectroscopic data are given below:

[m- $\left.\mathrm{C}_{6} \mathrm{H}_{4}\left(\mathrm{CH}_{2} \mathrm{ImMe}\right) 2^{+}\right][\mathrm{Cl}]_{2}$ :

${ }^{1} \mathrm{H}-\mathrm{NMR}$ (DMSO- $d_{6}$ ), $\delta_{H}$ ppm: 9.12 (s, 2H, NCHN), 7.69-7.67 (d, 4H, NCHCHN), 7.40-7.49 (m, 4H, $\left.\mathrm{C}_{6} \mathrm{H}_{4}\right), 5.41\left(\mathrm{~s}, 4 \mathrm{H},-\mathrm{CH}_{2}\right), 3.85\left(\mathrm{~s}, 6 \mathrm{H}, 2 \times \mathrm{CH}_{3}\right)$.

${ }^{13}$ C-NMR (DMSO- $d_{6}$ ) $\delta$ ppm: $36.15,51.96,122.71,124.46,128.44,129.08,130.29$, 135.86, 137.08

$\left[\mathrm{m}-\mathrm{C}_{6} \mathrm{H}_{4}\left(\mathrm{CH}_{2} \mathrm{ImMe}\right) 2^{+}\right]\left[\mathrm{BF}_{4}\right]_{2}$ :

${ }^{19}$ F-NMR (DMSO-d6) $\delta_{F}(\mathrm{ppm}):-148.17\left(\mathrm{~s}, \mathrm{BF}_{4}\right)$.

$\left[\mathrm{m}-\mathrm{C}_{6} \mathrm{H}_{4}\left(\mathrm{CH}_{2} \mathrm{ImMe}\right) 2^{+}\right]\left[\mathrm{PF}_{6}\right]_{2}$ :

${ }^{19}$ F-NMR (DMSO- $\left.d_{6}\right) \delta$ ppm: $-69.63,-70.82$.

${ }^{31}$ P-NMR (DMSO- $d_{6}$ ) $\delta$ ppm: -133.72, -137.27, -140.78, -144.30, -147.81, -151.19, 154.71(sept, $\mathrm{PF}_{6}{ }^{-}$)

$\left[\mathrm{m}-\mathrm{C}_{6} \mathrm{H}_{4}\left(\mathrm{CH}_{2} \mathrm{ImMe}\right) 2_{2}^{+}\right]\left[\mathrm{NTf}_{2}\right]_{2}$ :

${ }^{19} \mathrm{~F}-\mathrm{NMR}\left(\mathrm{DMSO}-\mathrm{d}_{6}\right) \delta_{\mathrm{F}}(\mathrm{ppm}):-79.36\left(\mathrm{~s},\left[\mathrm{NTF}_{2}{ }^{-}\right]\right.$). 

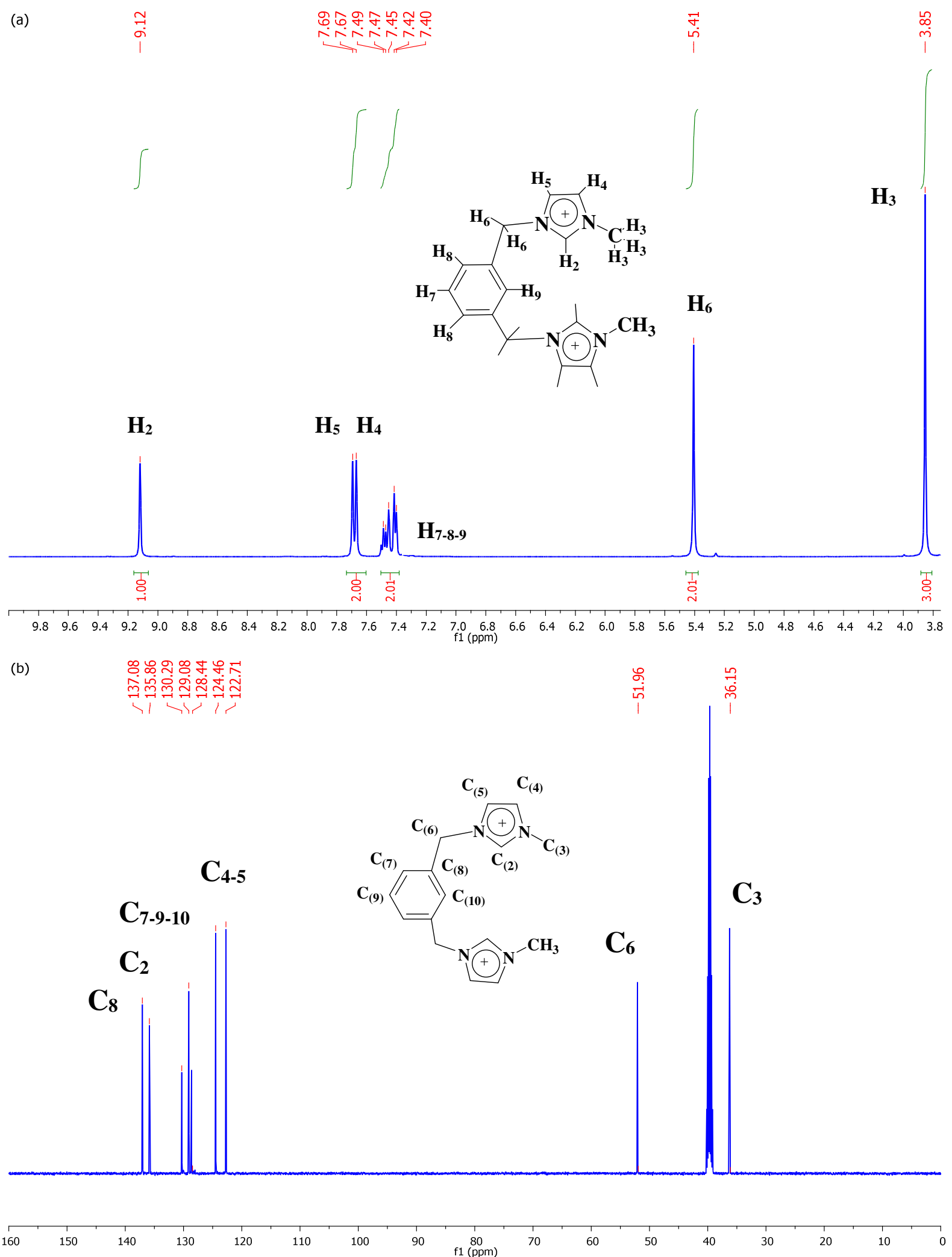

Figure 1. ${ }^{1} \mathrm{H}$ NMR (500 MHz) (a) and ${ }^{13} \mathrm{C}$ NMR (125.75 MHz) (b), spectra of [m$\left.\mathrm{C}_{6} \mathrm{H}_{4}\left(\mathrm{CH}_{2} \mathrm{ImMe}\right) 2^{+}\right]\left[\mathrm{Cl}^{-}\right]_{2}$ 


\subsection{THERMAL ANALYSIS}

Concomitant measurements of thermogravimetry (TGA) and differential thermal analysis (DTA) were performed by means of a Setaram Setsys Evolution 1200 TG System, with a fixed temperature rate of $5^{\circ} \mathrm{C} / \mathrm{min}$, in an argon flux of $60 \mathrm{ml} / \mathrm{min}$. For each sample, an initial mass of $\sim 20 \mathrm{mg}$ was used.

\subsection{VIBRATIONAL SPECTROSCOPY}

Infrared spectroscopy data were acquired by attenuated total reflectance spectra on a Vertex 70-RAM II Bruker spectrometer (Bruker Analytical, Madison, WI) operating with a Golden Gate TM diamond ATR accessory (Specac Ltd., Slough, UK). FTIR/ATR spectra [3500- $600 \mathrm{~cm}^{-1}$ ] were collected with a nominal resolution of $1 \mathrm{~cm}^{-}$

${ }^{1}$ by co-adding 64 scans for each spectrum. Only for the sample containing $\mathrm{Cl}^{-}$as anion, an additional spectrum was acquired in transmission mode by means of an Agilent Cary 660 with a resolution of $1 \mathrm{~cm}^{-1}$ in the frequency range between 4000 and $400 \mathrm{~cm}^{-1}$, by dissolving the ionic salt in $\mathrm{KBr}$ in the proportion 1:100 in mass. The measurement was the mean of 100 scans. Prior of this measurement the sample was kept at $80^{\circ} \mathrm{C}$ for 48 hours in order to increase its crystallinity and remove hydration water.

FT-RAMAN spectra were acquired by means of a Vertex 70-RAM II Bruker FTRAMAN spectrometer. This instrument is equipped with a Nd:YAG laser (yttrium aluminium garnetcrystal doped with triply ionized neodymium) with a wavelength of $1064 \mathrm{~nm}$ and a maximum power of $1.5 \mathrm{~W}$. The measurement accessory is prealigned; only the Z-axis of the scattered light is adjusted to set the sample in the appropriate position regarding the focal point. The RAM II spectrometer is equipped with a liquid-nitrogen cooled Ge detector. FT-RAMAN spectra [3500-150 cm-1] were collected with $1 \mathrm{~cm}^{-1}$ nominal resolution by co-adding 128 scans for each spectrum at room temperature.

\section{COMPUTATIONAL}

The isolated cation (m-xylene) was investigated computationally by means of the Spartan software [23-24]. Concerning the anions their spectra are well known both from an experimental and computational point of view [25-26]. 


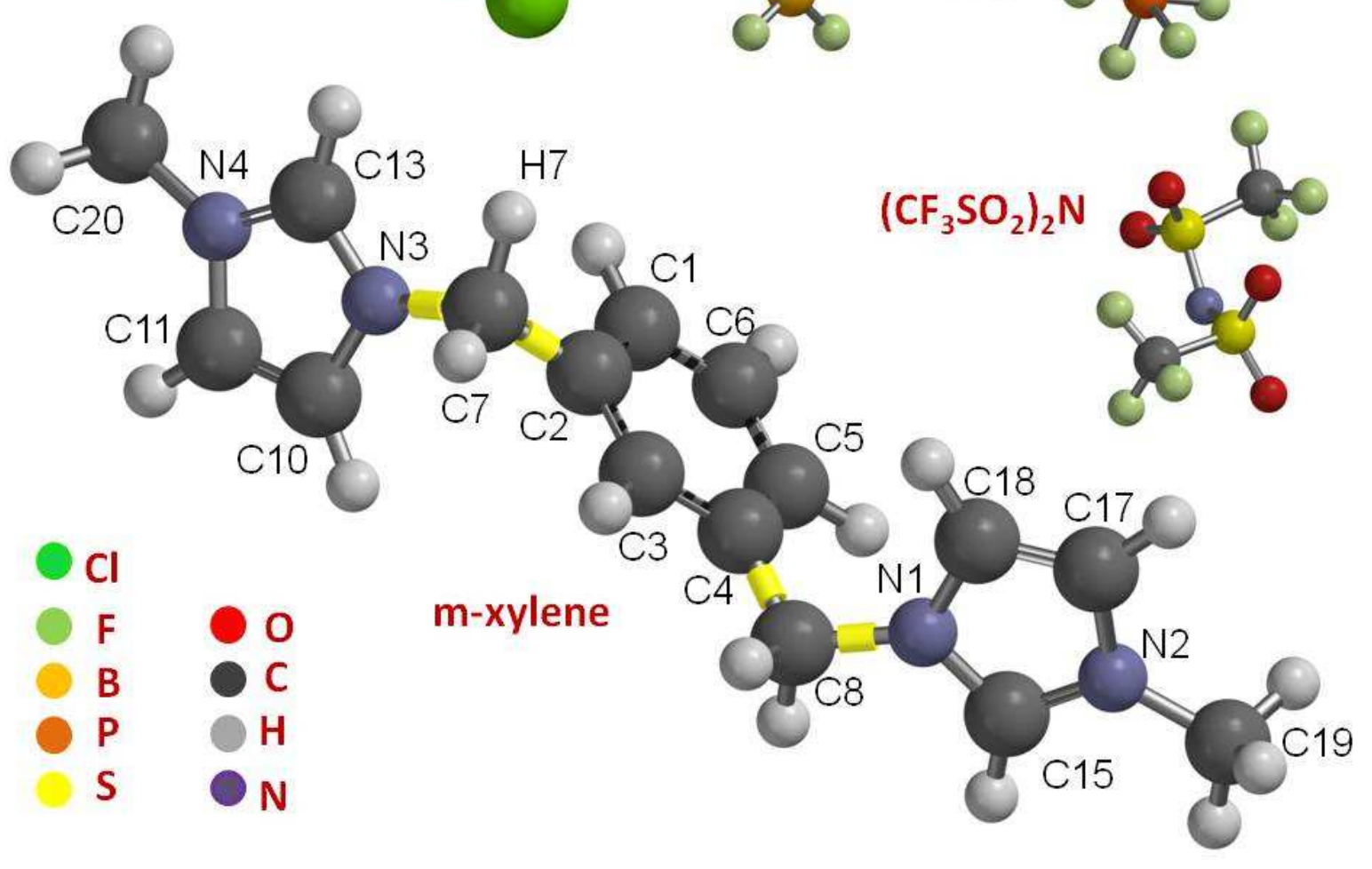

Figure 2. Schematics of the cation with labels identifying the atoms whose distances and angles are reported in Table 1 and schematics of the different anions.

A preliminary investigation of the possible conformational geometries of the $m$-xylene cation was performed at the molecular mechanics level. The investigation of the possible stable structures started with a systematic search, varying the four dihedral angles that define the ionic structure highlighted in Figure 2. The Spartan software can automatically investigate up to 200 structures; therefore, we chose the steps of the angle variations in order to have a lower number of possible structures. The dihedral angles $\mathrm{C} 3 \mathrm{C} 2 \mathrm{C} 7 \mathrm{~N} 3$ and $\mathrm{C} 3 \mathrm{C} 4 \mathrm{C} 8 \mathrm{~N} 1$ were varied by steps of $60^{\circ}$, while the two dihedral angles $\mathrm{C} 2 \mathrm{C} 7 \mathrm{~N} 3 \mathrm{C} 13$ and $\mathrm{C} 4 \mathrm{C} 8 \mathrm{~N} 1 \mathrm{C} 15$ were varied by $180^{\circ}$, so that in total we investigated $6 \times 6 \times 2 \times 2=144$ possible structures. An optimization of these structures was performed by DFT calculations using the $6-31 \mathrm{G}^{* *}$ basis set and the B3LYP theory, as largely performed in the previous literature for ionic liquids [25-28]. After the optimization, we obtained many degenerate geometries, that were removed from the following procedures. The vibration frequencies and the infrared intensity and Raman activity of the optimized structures having an energy not higher than 5 
$\mathrm{kJ} / \mathrm{mol}$ from the lowest energy conformer were calculated by means of the Spartan software. Only 7 of them had all positive vibrational frequencies and can therefore, be considered as stable points of the potential energy surface. In order to compare the experimental infrared and Raman spectra with the calculated one, we constructed expected IR and Raman spectra summing Gaussian curves centered at each calculated vibration frequency, with an intensity proportional to the calculated one and a fixed line width of $10 \mathrm{~cm}^{-1}$.

Moreover, the optimized geometry of the four ionic couples of $m$-xylene with $2 \mathrm{Cl}^{\text {', }} 2$ $\mathrm{BF}_{4}^{-}, 2 \mathrm{PF}_{6}{ }^{-}$or $2 \mathrm{NTf}_{2}{ }^{-}$anions were obtained by DFT calculations using the $6-31 \mathrm{G}^{* *}$ basis set and the B3LYP theory.

\section{RESULTS AND DISCUSSION}

\subsection{COMPUTATIONAL RESULTS}

Table 1 reports the values of the four dihedral angles of the seven stable points of the potential energy surface (all vibrational frequencies are positive), after the optimization of geometries by means of DFT calculations using the $6-31 \mathrm{G}^{* *}$ basis set and the B3LYP theory. The two dihedrals $\mathrm{C} 3 \mathrm{C} 2 \mathrm{C} 7 \mathrm{~N} 3$ and $\mathrm{C} 3 \mathrm{C} 4 \mathrm{C} 8 \mathrm{~N} 1$ define the relative orientation of the two imidazolium rings, while the two dihedrals $\mathrm{C} 4 \mathrm{C} 8 \mathrm{~N} 1 \mathrm{C} 15$ and $\mathrm{C} 2 \mathrm{C} 7 \mathrm{~N} 3 \mathrm{C} 13$ describe the rotation of the imidazolium rings around its axis with respect to the xylene groups. In Table 1 also the values of the energy difference with respect to the lowest energy conformer are reported.

Table 1. The label, the dihedral angles and the difference in relative energy with respect to the lowest energy one of the seven cation conformers.

\begin{tabular}{|l|l|l|l|l|l|}
\hline Label & $\begin{array}{l}\text { Dihedral } \\
\text { C3C2C7N3 }\end{array}$ & $\begin{array}{l}\text { Dihedral } \\
\text { C3C4C8N1 }\end{array}$ & $\begin{array}{l}\text { Dihedral } \\
\text { C2C7N3C13 }\end{array}$ & $\begin{array}{l}\text { Dihedral } \\
\text { C4C8N1C15 }\end{array}$ & $\begin{array}{l}\text { Relative } \\
\text { Energy } \\
(\mathrm{kJ} / \mathrm{mol})\end{array}$ \\
\hline $\mathrm{A}$ & -123.52 & -123.99 & -130.52 & -131.32 & 0.00 \\
\hline $\mathrm{B}$ & 122.49 & 85.63 & 133.55 & -145.72 & 3.45 \\
\hline $\mathrm{C}$ & 125.88 & 118.85 & -45.82 & 133.75 & 3.61 \\
\hline $\mathrm{D}$ & -121.84 & -122.43 & 37.64 & -129.76 & 3.70 \\
\hline $\mathrm{E}$ & -143.20 & 136.94 & -124.46 & 126.78 & 4.22 \\
\hline $\mathrm{F}$ & -97.20 & -119.24 & -14.94 & -132.60 & 4.60 \\
\hline $\mathrm{G}$ & 88.98 & 123.36 & 30.42 & 131.92 & 4.73 \\
\hline
\end{tabular}


Table 2 displays some significative distances and angles of the lowest energy conformer. Similar values are obtained also for the other conformers, except for the four dihedral angles reported in Table 1. A comparison with experimental data is not possible because no study of the structure of meta-xylyl linked bis-1methylimidazolium compounds is available. However, the presently calculated values of bond lengths and angles well compares with those obtained both computationally [20] and experimentally from X-Ray diffraction data [29-30] for the $p$ xylene compounds.

Table 2. Some significative distances and angles calculated for the lowest energy conformer of $m$-xylene. The labels of atoms refer to Figure 2.

\begin{tabular}{|l|l|l|l|l|l|l|l|l|l|}
\hline \multicolumn{7}{|c|}{ distances (文) } \\
\hline C1-C2 & C2-C7 & C7-H7 & C7-N3 & N3-C10 & N3-C13 & C10-C11 & C11-N4 & $\begin{array}{l}\text { C13- } \\
\text { N4 }\end{array}$ & N4-C20 \\
\hline 1.400 & 1.516 & 1.093 & 1.484 & 1.384 & 1.341 & 1.363 & 1.383 & 1.337 & 1.473 \\
\hline $\begin{array}{l}\text { C3-C2- } \\
\text { C7 }\end{array}$ & $\begin{array}{l}\text { C2-C7- } \\
\text { N3 }\end{array}$ & $\begin{array}{l}\text { C7-N3- } \\
\text { C10 }\end{array}$ & & & & & & & \\
\hline 119.80 & 113.36 & 126.30 & & & & & & & \\
\hline
\end{tabular}

Additionally Table $\mathbf{S 1}$ of the Supplementing Information reports the calculated vibrational frequencies, their infrared intensities and the Raman activities, for all seven conformers.

\subsection{THERMAL ANALYSIS}

Decomposition studies are performed to investigate the influence that the structural parameters of anions have on the thermal degradation process of dicationic ILs, and to determine which ILs can be used in applications involving high temperatures [31]. 


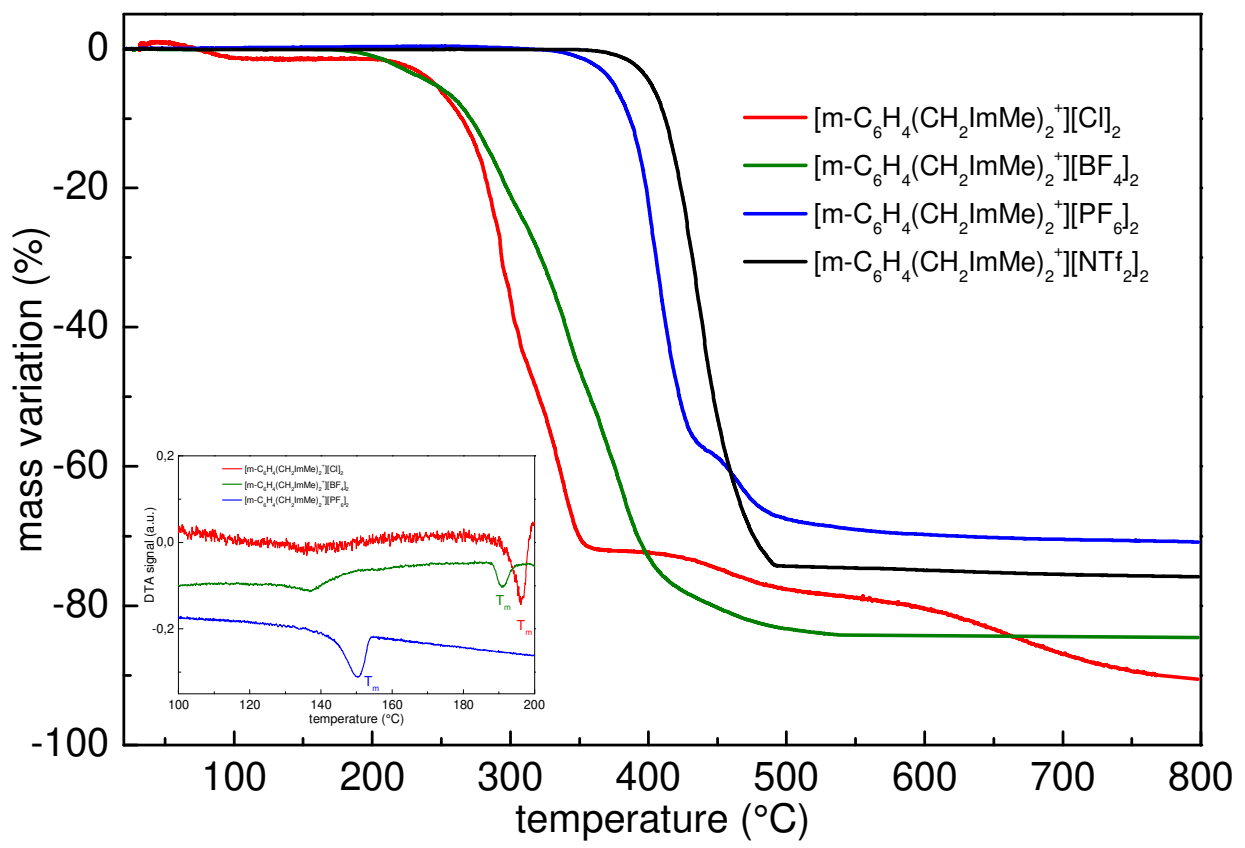

Figure 3. TGA and differential thermal analysis (DTA) thermographs for the synthesized dicationic ionic liquids (ILs).

Figure 3 shows the decomposition profiles of the four dicationic ILs based on the [ $\mathrm{m}$ $\left.\mathrm{C}_{6} \mathrm{H}_{4}\left(\mathrm{CH}_{2} \mathrm{ImMe}\right)_{2}\right]$ dication from room-temperature up to $800^{\circ} \mathrm{C}$. The present dicationic ILs were found to be thermally stable in a wide range of temperature. As reported for most dicationic ILs, the dicationic IL containing [NTf $]^{-}$is more stable than those containing $\left[\mathrm{PF}_{6}\right]^{-}$, $\left[\mathrm{BF}_{4}\right]^{-}$and $\mathrm{Cl}^{-}$[32-33]. We observed that dichloride salt begins to decompose (lose $0.07 \mathrm{mg} \approx 0.5 \%$ of its initial mass) at $83^{\circ} \mathrm{C}$ probably due to the water of hydratation; the real decomposition of this salt is revealed in the range $300-357^{\circ} \mathrm{C}$ (lose of $\approx 72 \%$ ), to reach the maximum level of loss $(\approx 90 \%)$ at $800^{\circ} \mathrm{C}$. The analogue salt containing $\mathrm{BF}_{4}$ anion loses the same amount compared to the halide salt, of its weight $\approx 0.5 \%$ at $190^{\circ} \mathrm{C}$, but only $21 \%$ at $300^{\circ} \mathrm{C}$, and reaches $84 \%$ of loss weight at $800^{\circ} \mathrm{C}$. The two other salts containing $\left[\mathrm{PF}_{6}\right]^{-}$and $\left[\mathrm{NTf}_{2}\right]^{-}$have similar thermal behavior and are stable in a wider temperature range. The thermal stability of the salts generally increases in the order: halides $<\left[\mathrm{BF}_{4}\right]^{-}<\left[\mathrm{PF}_{6}\right]^{-}<$ $\left[\mathrm{NTf}_{2}\right]$. This trend indicates that the thermal stability of the dicationic ILs, therefore, depends on the anionic species, which have a significant impact on their thermal behavior, as observed in the imidazolium salts with these anions [34-35]. To realize the relationship of thermal behavior of the presently investigated dicationic ILs with 
the structure of anion is difficult, probably due to a large number of parameters such as ion size, shape, charge density, polarizability and flexibility of ions and planarity of molecular geometry. The lower thermal stability of the dichloride salt relative to those containing $\left[\mathrm{BF}_{4}\right]^{-},\left[\mathrm{PF}_{6}\right]^{-}$and $\left[\mathrm{NTf}_{2}\right]^{-}$, and his decomposition rate varied significantly during the pyrolysis, due to residual water. In addition to that, it is more nucleophilic than the larger fluoride containing anions and thus decompose by $\mathrm{SN}_{1}$ or $\mathrm{SN}_{2}$ nucleophilic decomposition [35-36]. The pyrolysis of the imidazolium based salts has been reported to proceed most likely via $\mathrm{SN}_{2}$ process, and therefore, change in the basicity and/or nucleophilicity of the anions is likely to bring about a change in the thermal stability of the ILs [37]. The results indicated that dicationic ILs containing $\left[\mathrm{NTf}_{2}\right]^{-}$shows slightly higher stability, they are less nucleophilic compared to the halides ones, which provides higher thermal stabilities compared to others dicationic ILs. This result may be attributed to the size of the $\left[\mathrm{NTf}_{2}\right]^{-}$that is much larger and possesses higher polarizability than perfluorinated $\left[\mathrm{PF}_{6}\right]^{-}$and $\left[\mathrm{BF}_{4}\right]^{-}$ions. Moreover, the better flexibility and charge distribution of $\left[\mathrm{NTf}_{2}\right]^{-}$tend to increase the interactions (attractive forces), and finally the molecular weight of the combination cation/anion.

It was reported that the melting point $\left(T_{m}\right)$ of a compound is determined by the strength of its crystal lattice, which in turn is controlled by three main factors: intermolecular forces, molecular symmetry, and the conformational degrees of the freedom of a molecule [38-39]. Increasing the size of the anion generally results in weaker coulombic interactions in the crystal lattice, poor packing of the ions, and a decrease in the melting temperatures ( $\left.\mathrm{Tm}: \mathrm{Cl}, \mathrm{Br}>\mathrm{PF}_{6}>\mathrm{BF}_{4}>\mathrm{NTf}_{2}\right)$ [40].

Table 3. Thermal properties of synthesized dicationic ILs: melting point, $\mathrm{T}_{\mathrm{m}}$, and decomposition temperature, $\mathrm{T}_{\mathrm{d}}$.

\begin{tabular}{|c|c|c|c|}
\hline Dicationic ILs & Physical State at $25^{\circ} \mathrm{C}$ & $\mathrm{T}_{\mathrm{m}}\left({ }^{\circ} \mathrm{C}\right)$ & $\mathrm{T}_{\mathrm{d}}\left({ }^{\circ} \mathrm{C}\right)$ \\
\hline$\left[\mathrm{m}-\mathrm{C}_{6} \mathrm{H}_{4}\left(\mathrm{CH}_{2} \mathrm{ImMe}\right)_{2}\right][\mathrm{Cl}]_{2}$ & Solid & 196 & 357 \\
\hline$\left[\mathrm{m}-\mathrm{C}_{6} \mathrm{H}_{4}\left(\mathrm{CH}_{2} \mathrm{ImMe}\right)_{2}\right]\left[\mathrm{PF}_{6}\right]_{2}$ & Solid & 150 & 476 \\
\hline$\left[\mathrm{m}-\mathrm{C}_{6} \mathrm{H}_{4}\left(\mathrm{CH}_{2} \mathrm{ImMe}\right)_{2}\right]\left[\mathrm{BF}_{4}\right]_{2}$ & Solid & 136 & 407 \\
\hline$\left[\mathrm{m} \mathrm{C}_{6} \mathrm{H}_{4}\left(\mathrm{CH}_{2} \mathrm{ImMe}\right)_{2}\right]\left[\mathrm{NTf}_{2}\right]_{2}$ & Liquid & -- & 491 \\
\hline
\end{tabular}


The comparison of the $T_{m}$ values of the dichloride salt with those containing the $\left[\mathrm{BF}_{4}\right]$ ; $\left[\mathrm{PF}_{6}\right]^{-}$and $\left[\mathrm{NTf}_{2}\right]^{-}$clearly shows the impact of the anion symmetry (see Table 3). For the same cation, the salts with fluoro anions $\left(\left[\mathrm{BF}_{4}\right]^{-} \ldots\right)$ generally exhibit a lower melting point than those with higher symmetry $[\mathrm{Cl}]$; , because this fluoro anions not only possesses chemical and electrochemical stability, but they also have low symmetry, high flexibility, and a weakly coordinating nature. These results suggest that packing efficiency of the salt could be disrupted by reducing the anion symmetry, thus lowering the melting point.

\subsection{INFRARED SPECTROSCOPY}

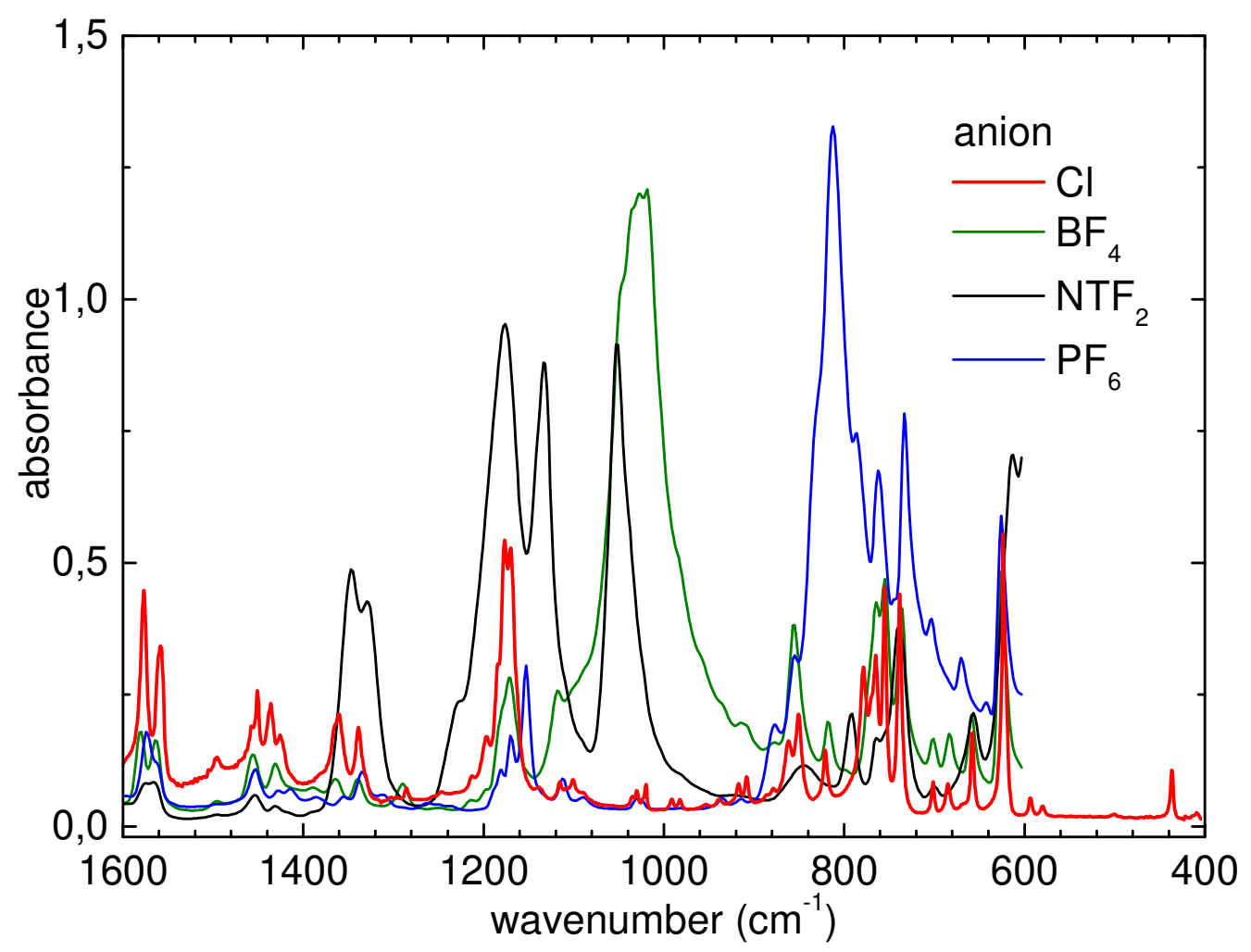

Figure 4. Comparison of the infrared absorption spectra of the four dicationic ILs.

Figure 4 reports the infrared absorbance spectra of the four dicationic ILs synthesized in this study. Most of the absorption lines of the dicationic IL containing $\mathrm{NTF}_{2}$ as anion are due to the vibrations of the anion, as reported in Table 4. In the dicationic ILs with the $\mathrm{BF}_{4}$ anion the strong absorption lines centered around 761 and $1026 \mathrm{~cm}^{-1}$ are due to the anion; in the dicationic IL with $\mathrm{PF}_{6}$, the intense lines 
around 742 and $852 \mathrm{~cm}^{-1}$ are attributable to the vibrations of the anion [25]. Apart for these lines, the other absorption bands are common to the dicationic ILs and are therefore attributable to the vibrations of the common m-xylene cation. Their detailed attributions are reported in Table 4.

Table 4. Observed FTIR/ATR bands and their assignment of the four dicationic ILs. $(\mathrm{vw}=$ very weak; $\mathrm{w}=$ weak $; \mathrm{m}=$ medium, $\mathrm{s}=$ strong; $\mathrm{sh}=$ shoulder $; \mathrm{v}=\mathrm{Str}=$ stretch; $\delta=$ deformation; bend $=$ bending deformation; $\omega=$ wagging; $\rho=$ rocking; $\gamma=$ out-ofplane; $\mathrm{s}$ = symmetric; as = antisymmetric).

\begin{tabular}{|c|c|c|c|c|c|}
\hline \multicolumn{4}{|c|}{$\left[\mathrm{m}-\mathrm{C}_{6} \mathrm{H}_{4}\left(\mathrm{CH}_{2} \mathrm{ImMe}\right)_{2}\right]$} & \multirow{2}{*}{ Vibrational assignment } & \multirow{2}{*}{ Refs } \\
\hline$[\mathrm{Cl}]_{2}$ & {$\left[\mathrm{PF}_{6}\right]_{2}$} & {$\left[\mathrm{BF}_{4}\right]_{2}$} & {$\left[\mathrm{NTf}_{2}\right]_{2}$} & & \\
\hline & & & & Range: $3300-2700 \mathrm{~cm}^{-1}$ & \\
\hline & $3170(\mathrm{~s})$ & $3161(w)$ & $3157(\mathrm{~m})$ & $\mathrm{H}-\mathrm{C}-\mathrm{C}-\mathrm{H}$ symmetric stretch & {$[44] /[45] /[46 /[47] /[55] /[59] /[60] /[69]$} \\
\hline 3138(sh) & 3134(sh) & 3132(sh) & & $\mathrm{H}-\mathrm{C}-\mathrm{C}-\mathrm{H}$ asymmetric stretch & {$[44] /[45] /[46] /[47] /[55] /[59] /[60] /[69]$} \\
\hline 3115(sh) & 3120(sh) & $3116(w)$ & $3120(v w)$ & $\mathrm{H}-\mathrm{C}-\mathrm{C}-\mathrm{H}$ asymmetric stretch & $\begin{array}{l}{[44] /[45] /[46] /[47] /[55] /} \\
{[59] /[60] /[70]}\end{array}$ \\
\hline $3088(w)$ & & & & $\mathrm{v}(\mathrm{C}-\mathrm{H}) / \mathrm{v}(\mathrm{CH})$ & {$[55] /[70] /[70]$} \\
\hline $3059(w)$ & & & & $\mathrm{v}(\mathrm{C}-\mathrm{H})$ & {$[41] /[60] /[69] /[70]$} \\
\hline \multirow[t]{2}{*}{$2981(w)$} & 2974(vw) & $2970(v w)$ & 2968(vw) & $(\mathrm{N}) \mathrm{CH}_{3}$ asymmetric stretch, $\mathrm{CH}_{2} \mathrm{HCH}$ asym Str & {$[59] /[60] /[69] /[70]$} \\
\hline & & & & Range : $1700-900 \mathrm{~cm}^{-1}$ & \\
\hline $1660(\mathrm{~m})$ & & & & Imidazole ring : $\mathrm{C}=\mathrm{C}$ str, $\mathrm{N}=\mathrm{C}-\mathrm{N}$ str & [59] \\
\hline $1612(\mathrm{vw})$ & $1631(w)$ & 1618(vw) & 1612(w) & Phenyl ring $: \vee \mathrm{C}=\mathrm{C}$ & {$[41] /[42] /[44] /[45] /[46] /[47]$} \\
\hline 1595(vw) & & & & v $\mathrm{C}=\mathrm{C}$, Asym Str $\mathrm{CH}_{2}(\mathrm{~N}) / \mathrm{CH}_{3}(\mathrm{~N}) \mathrm{CN}$ Str & {$[55] /[58]$} \\
\hline $1573(\mathrm{~m})$ & $1573(\mathrm{~m})$ & 1581(w) & $1571(\mathrm{vw})$ & Phenyl ring : $\mathrm{C}=\mathrm{C}$ stretching, $(\mathrm{N}) \mathrm{CH}_{2}$ str & {$[41] /[42] /[44] /[45] /[46] /[47]$} \\
\hline $1558(\mathrm{~m})$ & & 1562(w) & & Phenyl ring : $\mathrm{vC}=\mathrm{C}$, Imidazole ring $\mathrm{v}(\mathrm{N}=\mathrm{C})$ & {$[41] /[42] /[44] /[45] /[46] /[47]$} \\
\hline 1494(vw) & $1496(v w)$ & 1494(vw) & & $\begin{array}{l}\text { Imidazole ring ip asym str, }(\mathrm{N}) \mathrm{CH}_{3} \mathrm{HCH} \text { sym } \\
\text { bend }\end{array}$ & {$[53] /[58] /[69] /[70]$} \\
\hline 1471(sh) & & & & $\delta\left(\mathrm{CH}_{2}\right) / \mathrm{CCH} \mathrm{HCH}$ as bend & {$[44] /[55] /[60] /[70]$} \\
\hline $1446(\mathrm{~m})$ & 1452(w) & 1454(w) & 1452(vw) & $\delta\left(\mathrm{CH}_{2}\right) / \mathrm{CCH} \mathrm{HCH}$ as bend & {$[44] /[55] /[60]$} \\
\hline \multirow[t]{2}{*}{$1429(\mathrm{sh})$} & 1427(vw) & $1429(w)$ & $1431(v w)$ & $\begin{array}{l}\text { Imidazole ring :C-N/ C=N stretching band, } \\
\delta_{s}\left(\mathrm{CH}_{2}\right), \mathrm{C}-\mathrm{H} \text { deformation }\end{array}$ & {$[41] /[42] /[44] /[45] /[46] /[47] /[58]$} \\
\hline & $1413(\mathrm{vw})$ & & & $\rho(\mathrm{N}-\mathrm{H})$ & {$[41] /[55] /[61]$} \\
\hline 1383(w) & 1384(vw) & & & $\rho\left(\mathrm{CH}_{2}\right), \rho(\mathrm{CH}) / \delta\left(\mathrm{CH}_{2}\right)[\mathrm{op}], \omega(\mathrm{CH})$ & {$[41] /[60] /[61]$} \\
\hline $1359(w)$ & $1353(v w)$ & & 1346(m) & $\begin{array}{l}\text { Imidazole ring :C-N/ C=N stretching band, } \\
\text { Trans }\left[\mathrm{NTf}_{2}\right]: \mathrm{v}_{\text {as }}\left(\mathrm{SO}_{2}\right),(\mathrm{N}) \mathrm{CH}_{2} \text { str, } \mathrm{v} \mathrm{CC}\end{array}$ & {$[41] /[42] /[43] /[44] /[45] /[46] /[47]$} \\
\hline \multirow[t]{2}{*}{$1328(w)$} & 1332(w) & $1338(v w)$ & $1328(\mathrm{~m})$ & $\begin{array}{l}\text { Imidazole ring }: \mathrm{C}-\mathrm{N} / \mathrm{C}=\mathrm{N} \text { stretching, } \mathrm{SO}_{2} \text { asym } \\
\text { str }\end{array}$ & {$[41] /[42] /[44] /[45] /[46] /[47]$} \\
\hline & $1311(\mathrm{sh})$ & & & $\rho \mathrm{C} 4-\mathrm{H}, \mathrm{C} 5-\mathrm{H}$, twist $\mathrm{CH}_{2}$ & {$[58]$} \\
\hline $1282(w)$ & $1261(\mathrm{vw})$ & $1290(v w)$ & & Phenyl ring: $\mathrm{C}-\mathrm{C}$ stretching, $\mathrm{v} \mathrm{BF}_{4}$ & {$[41] /[44] /[45] /[46] /[47] /[58]$} \\
\hline 1238(vw) & $1236(\mathrm{vw})$ & 1217(vw) & 1224(sh) & v CN, $\mathrm{CF}_{3}$ sym Str & [41] \\
\hline \multirow[t]{2}{*}{$1195(\mathrm{vw})$} & & & & Ring $\mathrm{s} \mathrm{CH}_{2}(\mathrm{~N})$ and $\mathrm{CH}_{3}(\mathrm{~N}) \mathrm{CN}$ Str & {$[44] /[55]$} \\
\hline & $1178(\mathrm{sh})$ & $1170(\mathrm{~m})$ & 1174(s) & $\begin{array}{l}\text { Ring asym } \mathrm{Str} \mathrm{CH}_{2}(\mathrm{~N}) \text { and } \mathrm{CH}_{3}(\mathrm{~N}) \mathrm{CN} \mathrm{Str} / \mathrm{CC} \\
\mathrm{Str} \mathrm{BF}_{4} \mathrm{FBF} \text { asym str }\end{array}$ & {$[44] /[53] /[55]$} \\
\hline $1153(\mathrm{~s})$ & $1151(\mathrm{~s})$ & & & $\delta \mathrm{CH},(\mathrm{N})-\mathrm{CH}_{2^{-}},(\mathrm{N})-\mathrm{CH}_{3}$ & {$[44] /[58]$} \\
\hline $1110(\mathrm{vw})$ & $1110(\mathrm{sh})$ & 1116(sh) & $1132(\mathrm{~s})$ & $\delta \mathrm{CH}$, ring $\mathrm{HCCH}$ sym bend, $\mathrm{CC}$ str & {$[53] /[55] /[57]$} \\
\hline $1091(w)$ & 1087(sh) & & $1051(s)$ & $\begin{array}{l}\text { Ring ip asym str, CC str, } \mathrm{NCH}_{3} \text { twist, SNS asym } \\
\text { str }\end{array}$ & {$[41] /[43][48] /[49] /[50] /[51] /[56]$} \\
\hline 1028(vw) & $1028(w)$ & $1026(\mathrm{~s})$ & & $\mathrm{CH}_{3} \mathrm{~N} \mathrm{Str} / \mathrm{CH}_{2} \mathrm{~N}$ Str , v C-C & {$[41] /[44] /[48] /[49] /[50] /[51] /[55]$} \\
\hline $1016(\mathrm{vw})$ & & $1016(\mathrm{~s})$ & & $\mathrm{BF}_{4}$ asym str, ring ip sym str & [53] \\
\hline 983(vw) & & & & $v$ CC, ring ip asym bend & [53] \\
\hline 960(vw) & & & & Ring ip sym bend, CC str & {$[53]$} \\
\hline $931(\mathrm{vw})$ & 933(vw) & 933(vw) & & $\rho_{\text {as }}\left(\mathrm{CH}_{2}\right), \mathrm{BF}_{4}$ asym str, $\gamma \mathrm{CH}$ & {$[53] /[44] /[55]$} \\
\hline 912(vw) & 912(vw) & 908(vw) & & $\gamma \mathrm{C}-\mathrm{H}$ & {$[58]$} \\
\hline
\end{tabular}




\begin{tabular}{|c|c|c|c|c|c|}
\hline & & & & Range : $900-600 \mathrm{~cm}^{-1}$ & \\
\hline 894(vw) & & & & $\mathrm{NC}(\mathrm{H}) \mathrm{N}$ bend/CCH bend & [55] \\
\hline $877(w)$ & 875(sh) & $877(\mathrm{vw})$ & & $\mathrm{NC}(\mathrm{H}) \mathrm{N}$ bend, $\rho_{\text {as }}\left(\mathrm{CH}_{2}\right)$ & {$[42] /[47] /[61]$} \\
\hline $840(w)$ & 852(sh) & $854(\mathrm{~m})$ & 844(vw) & $\mathrm{NC}(\mathrm{H}) \mathrm{N}$ bend /CCH bend / NC2(H)N CH bend & {$[42] /[43] /[55]$} \\
\hline $808(w)$ & $810(\mathrm{~s})$ & $815(w)$ & & $\mathrm{v}\left(\mathrm{PF}_{6}\right)$, Ring $\mathrm{CC}$ bend & {$[53] /[61]$} \\
\hline $788(w)$ & 783(vw) & 794(vw) & $789(w)$ & ring $\mathrm{HCCH}$ asym bend / CS St & {$[42] /[52] /[54] /[71]$} \\
\hline $760(v w)$ & $760(m)$ & $761(v w)$ & $762(\mathrm{vw})$ & $\begin{array}{l}\delta(\mathrm{HCCH}) / \text { ring } \mathrm{HCCH} \text { asym bend, } \mathrm{v}_{\mathrm{s}} \mathrm{SNS} \text {, } \\
\mathrm{BF}_{4} \text { sym str }\end{array}$ & {$[43] /[52] /[53] /[55]$} \\
\hline $748(w)$ & 742(vw) & $752(w)$ & $746(v w)$ & $\begin{array}{l}\text { Trans-[NTf } 2]: \delta s\left(\mathrm{CF}_{3}\right) \text {, ring } \mathrm{HCCH} \text { sym bend, } \\
\mathrm{CF}_{3} \text { sym bend, } \mathrm{v}\left(\mathrm{PF}_{6}\right), \mathrm{BF}_{4} \mathrm{FBF} \text { sym str }\end{array}$ & {$[42] /[43] /[53] /[55] /[61]$} \\
\hline $729(\mathrm{~m})$ & $731(\mathrm{~m})$ & $735(m)$ & $736(m)$ & $\begin{array}{l}\text { Anion interaction, } \mathrm{CH}_{2}(\mathrm{~N}) \text { and } \mathrm{CH}_{3}(\mathrm{~N}) \mathrm{CN} \text { str, } \\
\mathrm{CF}_{3} \text { sym bend }\end{array}$ & {$[42] /[43] /[52] /[55] /[61]$} \\
\hline 696(w) & 699(sh) & $698(w)$ & $696(\mathrm{vw})$ & Ring ip asym bend, $\mathrm{CH}_{2}(\mathrm{~N})$ str, $\mathrm{CH}_{3}(\mathrm{~N}) \mathrm{CN}$ str & {$[41] /[42]$} \\
\hline $675(w)$ & $667(w)$ & $679(w)$ & & $\omega(\mathrm{C}-\mathrm{H}), \delta \mathrm{CC}, \mathrm{C}=\mathrm{C}-\mathrm{H}$, Ring HCCH sym bend & {$[41] /[48] /[49] /[50] /[51] /[55] /[61]$} \\
\hline $655(w)$ & $640(v w)$ & $655(w)$ & $653(w)$ & $\mathrm{CH}_{2}(\mathrm{~N})$ str, $\mathrm{CH}_{3}(\mathrm{~N}) \mathrm{CN}$ str/v N-CH $\mathrm{CH}_{3}, \delta \mathrm{SNS}$ & {$[43] /[61]$} \\
\hline $613(s)$ & $622(s)$ & $622(\mathrm{~m})$ & $610(s)$ & $\begin{array}{l}\left.\mathrm{CH}_{3}(\mathrm{~N}) \mathrm{CN} \text { Str, } \text { Trans-[NTf } 2\right]: \delta S N S \text {, Phenyl } \\
\text { ring } \vee \mathrm{C}=\mathrm{C}, \vee\left(\mathrm{PF}_{6}\right)\end{array}$ & {$[41] /[42] /[43] /[44] /[45] /[46] /[47]$} \\
\hline
\end{tabular}
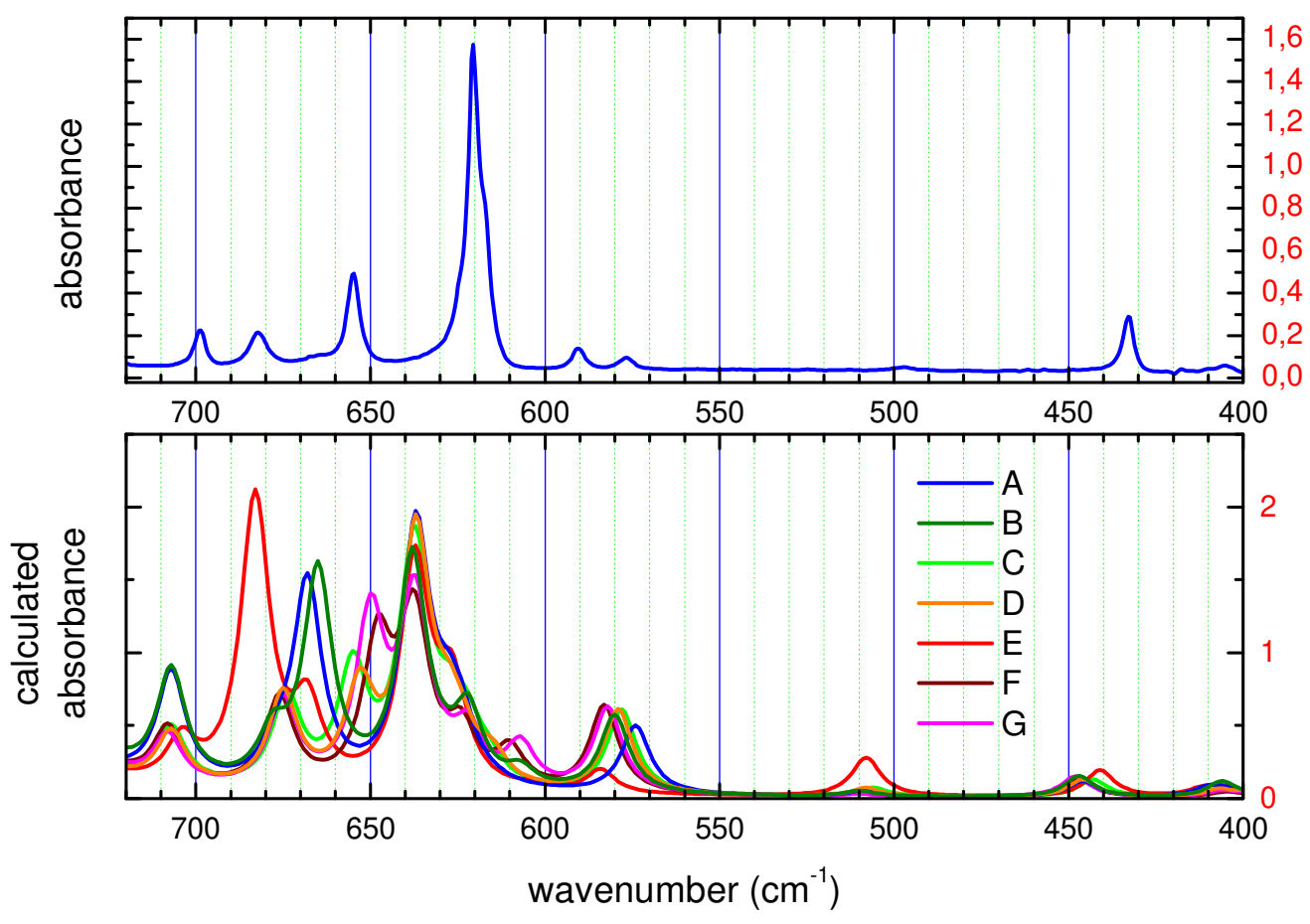

Figure 5. Comparison of the calculated infrared absorption spectra of the seven conformers of the cation and the experimentally measured spectrum of $\left[\mathrm{m}-\mathrm{C}_{6} \mathrm{H}_{4}\right.$ $\left.\left(\mathrm{CH}_{2} \mathrm{ImMe}\right)_{2}\right][\mathrm{Cl}]_{2}$. 
Figure 5 reports a comparison in the frequency range between 720 and $400 \mathrm{~cm}^{-1}$ of the calculated infrared absorption spectra of the seven conformers of the cation and the experimentally measured spectrum of $\left[\mathrm{m}-\mathrm{C}_{6} \mathrm{H}_{4}\left(\mathrm{CH}_{2} \mathrm{ImMe}\right){ }_{2}\right][\mathrm{Cl}] 2$, that has no contribution coming from the anion. It is evident that all calculated lines should be displaced towards lower frequency multiplying them by a factor in the range 0.97 0.99. The strong experimental absorption line centered around $620 \mathrm{~cm}^{-1}$ is found computationally around $636 \mathrm{~cm}^{-1}$ in all conformers. The lines measured around 654 $\mathrm{cm}^{-1}$ and $698 \mathrm{~cm}^{-1}$ are obtained computationally around 665 and $707 \mathrm{~cm}^{-1}$ in Conf A and around 668 and $707 \mathrm{~cm}^{-1}$ in Conf $B$ (the conformers with the lowest energies). The experimental absorption around $681 \mathrm{~cm}^{-1}$ could be attributed to Conf $\mathrm{E}$ that is expected to show a line around $683 \mathrm{~cm}^{-1}$ from the DFT calculations. The lack of any experimental absorption band between 610 and $636 \mathrm{~cm}^{-1}$ suggests the occurrence of very limited concentrations of conformers $\mathrm{B}, \mathrm{C}, \mathrm{F}$ and $\mathrm{G}$, that should present clear absorptions in this frequency range (after scaling).

\subsection{RAMAN SPECTROSCOPY}

Complementary to infrared absorption spectroscopy, Raman spectroscopy is a vibrational spectroscopy technique used in chemistry to identify molecules and study chemical bonding and intramolecular bonds.

In Figures 6, 7 and 8, we present a comparison between FT-Raman spectra of our four substituted dicationic ionic liquids (ILs) in the spectral ranges 1000-50, 17001000 and $3500-2700 \mathrm{~cm}^{-1}$, respectively. Figure S1, reported in the Supplementing Information, shows a comparison of the FT-Raman bands $\left[50-3500 \mathrm{~cm}^{-1}\right]$ of the studied dicationic ionic liquids; their assignment is reported in the following with a discussion for each spectral region.

\section{Region $1000-45 \mathrm{~cm}^{-1}$}

In this region, the most characteristic modes were discussed in several zones. The bands appearing in the zone [200- $50 \mathrm{~cm}^{-1}$ ] correspond to intermolecular vibrations with the spherical anions $\mathrm{Cl}^{-}, \mathrm{PF}_{6}, \mathrm{BF}_{4}^{-}$(the symmetry of the anions; the chloride anion has the most symmetrical sphere, whereas $\mathrm{PF}_{6}{ }^{-}$anion is an octahedron, $\mathrm{BF}_{4}{ }^{-}$ is an tetrahedron and the complexed [NTf $]^{-}$anion has the lowest symmetry in cis or 
trans forms and it also has S-N-S charge delocalization). Firstly, we observe three peaks for each anion except in the case of [NTf $]^{-}$, that has only two peaks at 72 and $192 \mathrm{~cm}^{-1}$.

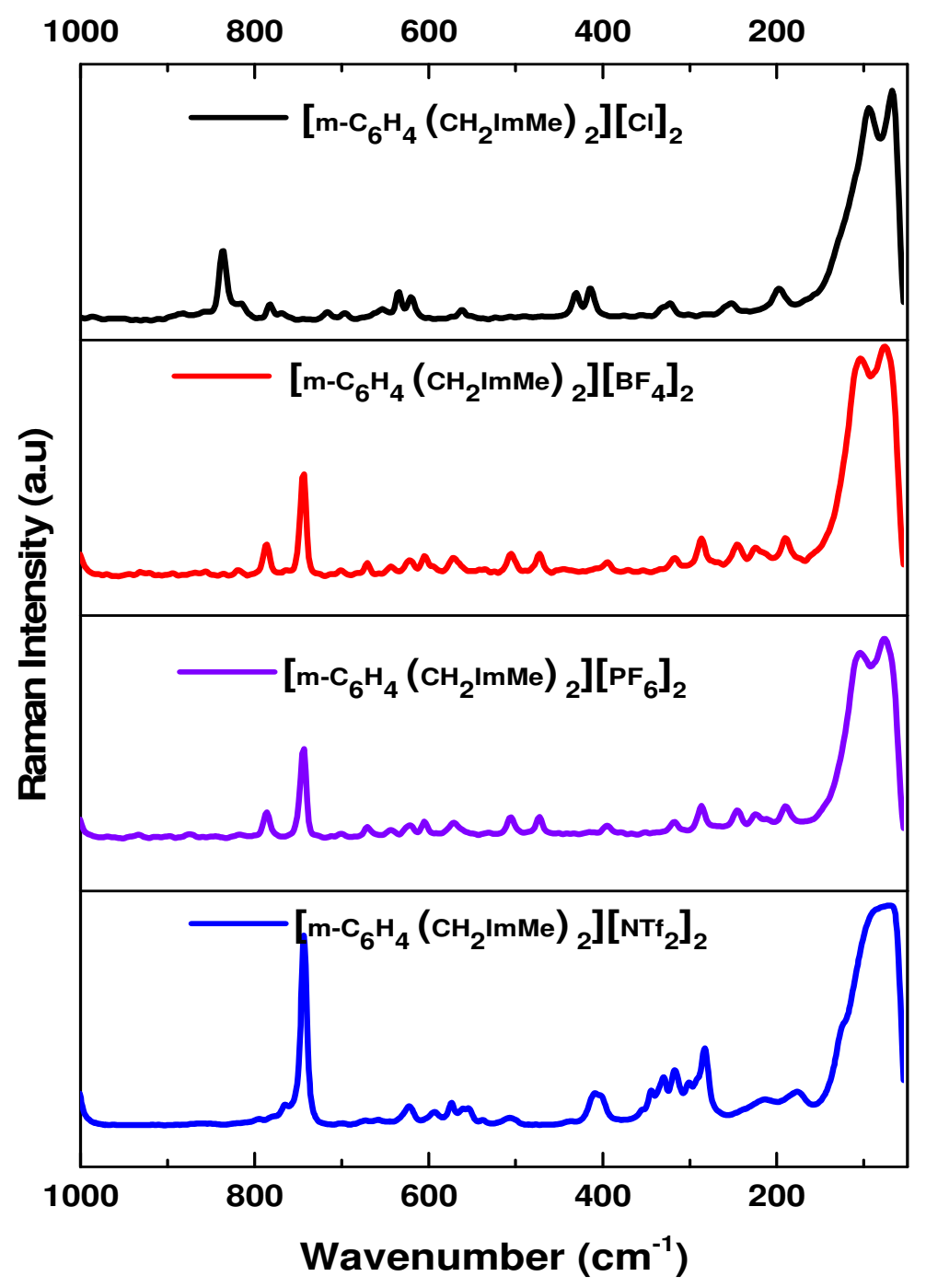

Figure 6. Raman spectra of the four dicationic ILs in the frequency range 1000- 45 $\mathrm{cm}^{-1}$.

In dichloride salt, we notice the presence of the following vibrational modes: 61,90 and $190 \mathrm{~cm}^{-1}$ assigned to intermolecular interactions. The same observation for the two fluorinated dicationic ILs, with slight difference in the position of the peak, which depends on the strength of the anion - cation interaction.We note that the size of the anion adjacent imidazolium rings affected the vibrational behavior of the modes 
situated in this spectral zone. The larger the anion, the higher the wavenumbers of the intermolecular Raman modes: 61 and $90 \mathrm{~cm}^{-1}$ for $\mathrm{Cl}^{-}$against 69; 95 / 70; 99 and $72 \mathrm{~cm}^{-1}$ for, $\mathrm{PF}_{6}^{-}, \mathrm{BF}_{4}^{-}$, and [ $\left.\mathrm{NTf}_{2}\right]^{-}$respectively. In the spectral zone [1000- $200 \mathrm{~cm}^{-}$ $\left.{ }^{1}\right]$, the changes are more spectacular, as we observed very different vibrational modes between dicationic ionic liquids according to the paired anion. In the case of the [NTf $]^{-}$anion, the $\mathrm{CF}_{3}$ asymmetric and symmetric deformation contributes to the 571,591 and $741 \mathrm{~cm}^{-1}$ bands respectively. In addition, other assignable modes of vibrations from the trans-[NTf $]^{-}$anion are: a SO 2 rocking (313 and $\left.326 \mathrm{~cm}^{-1}\right)$, a SO wagging (399 and $\left.404 \mathrm{~cm}^{-1}\right)$, a SO 2 symmetric deformation $\left(552 \mathrm{~cm}^{-1}\right)$ and a $\mathrm{SO}_{2}$ symmetric bending $\left(507 \mathrm{~cm}^{-1}\right)$. As for the other anions, a great similarity is observed between the spectra relating to $\mathrm{PF}_{6}$ and $\mathrm{BF}_{4}$ anions especially at $471 \mathrm{~cm}^{-1}$ as reported by Talaty et al. [46] and $742 \mathrm{~cm}^{-1}$ concerning the stretching and scissoring modes of vibration with a clear difference in intensities. Further two modes are observed at 620 and $766 \mathrm{~cm}^{-1}$, assigned to a bending, and symmetric stretching S$\mathrm{N}-\mathrm{S}$ respectively.

Moreover, in this zone, we showed the characteristic bands corresponding to all modes of the $\mathrm{C}-\mathrm{H}$ bond (in the $\mathrm{N}-\mathrm{C}(\mathrm{H})-\mathrm{N}$ fragment) and the stretching vibrations of the $\mathrm{N}$-heterocyclic ring that used before as the diagnostic bands in spectroscopic similar studies on molecules containing the imidazolium ring as investigated by Haddad et al. [9, 20-21, 65] and by Kausteklis et al. [69]. The bending motions of these bonds $(\mathrm{HCCH})$ have predominant contribution in the weak bands in the zone from 750 to $900 \mathrm{~cm}^{-1}$.

\section{Region 1700-1000 $\mathrm{cm}^{-1}$}

At the beginning of this spectral region, $(\mathrm{C}-\mathrm{C})$ skeletal modes are shown in the range [1000- $1200 \mathrm{~cm}^{-1}$ ], as intense band (symmetric stretching at $1005 \mathrm{~cm}^{-1}$ ). According to literature [42-45], all fundamental vibrations of the [NTf $]^{-}$anion are situated below $1400 \mathrm{~cm}^{-1}$, then two $\mathrm{SO}_{2}$ antisymmetric stretching modes are expected between 1335 and $1352 \mathrm{~cm}^{-1}$ and the symmetric one, $\mathrm{v}_{\mathrm{s}} \mathrm{SO}_{2}\left(1160 \mathrm{~cm}^{-1}\right)$, with contributions from the $\mathrm{v}_{\mathrm{s}} \mathrm{CF}_{3}$ symmetric stretching (intense polarized band at $1244 \mathrm{~cm}^{-1}$ ) [70]. In monocationic ionic liquids, the chloride was found in the plane of the ring, while $\mathrm{BF}_{4}$ is positioned over the ring and has short contacts not only with $\mathrm{H}$ C (2), but also with a proton of the methyl group, as suggested by Katsyuba et al. 
[58] thanks to the observation of the $\mathrm{BF}_{4}$ antisymmetric stretching mode of vibration $\left(1025 \mathrm{~cm}^{-1}\right)$. The spectral zone [1500-1400 $\mathrm{cm}^{-1}$ ] particularizes $\delta\left(\mathrm{CH}_{2}\right)$ bending [69].

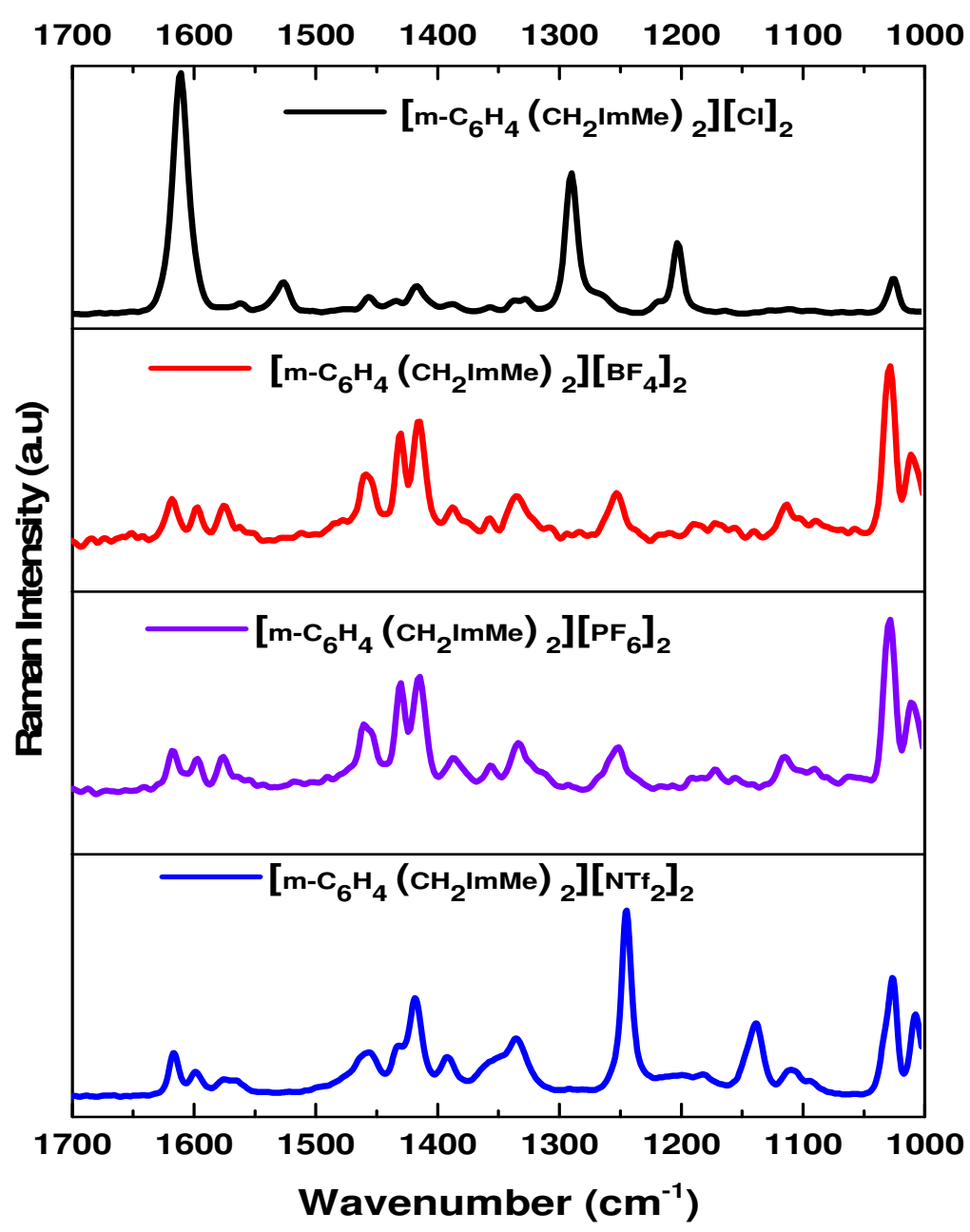

Figure 7. Raman spectra of the four dicationic ILs in the frequency range 1700-1000 $\mathrm{cm}^{-1}$.

The presence of the phenyl ring could be identifying also by $\mathrm{C}=\mathrm{C}$ stretching bands in the spectral range [1650 $\left.-1500 \mathrm{~cm}^{-1}\right]$, undoubtedly, the most characteristic vibration of the phenyl group is observed as a clear band around $1596 \mathrm{~cm}^{-1}$ for the fluorinated dicationic ILs, and $1610 \mathrm{~cm}^{-1}$ for the dichloride dicationic IL, that was assigned to $\mathrm{v}$ $(\mathrm{C}=\mathrm{C})$.

Region $3500-2700 \mathrm{~cm}^{-1}$ 
This region namely $\mathrm{C}-\mathrm{H}$ region, is characterized notably by the stretching vibrations of the $\mathrm{C}-\mathrm{H}$ bonds occur in the range from 3000 to $\sim 2700 \mathrm{~cm}^{-1}$ attributed to aliphatic $\mathrm{C}-\mathrm{H}$ symmetric and asymmetric stretching modes, while the aromatic $\mathrm{CH}$ groups vibrate at higher frequency manifesting between 3200 and $3000 \mathrm{~cm}^{-1}$. The band observed in the Raman spectrum near $2970 \mathrm{~cm}^{-1}$ can be assigned to a vas $\mathrm{CH}_{3}$ asymmetric stretching, as reported by Kausteklis et al. [69-70]. Moreover, the $\mathrm{C}-\mathrm{H}$ stretching vibration bands of the aromatic phenyl ring, the methylene and the methyl group attached to the imidazolium ring appear in the Raman spectra at 3027, 3043, $3065 \mathrm{~cm}^{-1}$ for $\left[\mathrm{m}-\mathrm{C}_{6} \mathrm{H}_{4}\left(\mathrm{CH}_{2} \mathrm{ImMe}\right)_{2}{ }_{2}\right][\mathrm{Cl}]_{2} ; 3071 \mathrm{~cm}^{-1}$ for $\left[\mathrm{m}-\mathrm{C}_{6} \mathrm{H}_{4}\left(\mathrm{CH}_{2} \mathrm{lmMe}\right)_{2}{ }^{+}\right]\left[\mathrm{BF}_{4}\right]_{2}$; $3031,3071 \mathrm{~cm}^{-1}$ for $\left[\mathrm{m}_{-} \mathrm{C}_{6} \mathrm{H}_{4}\left(\mathrm{CH}_{2} / \mathrm{mMe}_{2}\right)_{2}^{+}\left[\mathrm{PF}_{6}\right]_{2} ; 3022,3075 \mathrm{~cm}^{-1}\right.$ for $[\mathrm{m}-$ $\left.\mathrm{C}_{6} \mathrm{H}_{4}\left(\mathrm{CH}_{2} \mathrm{ImMe}\right)_{2}{ }^{+}\right]\left[\mathrm{NTF}_{4}^{-}\right]_{2}$. The $\mathrm{C}-\mathrm{H}$ stretching of the imidazole ring are observed at $3119,3152 \mathrm{~cm}^{-1}$ for $\left[\mathrm{m}-\mathrm{C}_{6} \mathrm{H}_{4}\left(\mathrm{CH}_{2} \mathrm{ImMe}\right)_{2}+\right][\mathrm{Cl}] 2,3127,3158,3179 \mathrm{~cm}^{-1}$ for $[\mathrm{m}-$ $\mathrm{C}_{6} \mathrm{H}_{4}\left(\mathrm{CH}_{2} \mathrm{ImMe}\right)_{2}+\left[\mathrm{PF}_{6}{ }^{-}\right] 2,3135,3158,3179 \mathrm{~cm}^{-1}$ for $\left[\mathrm{m}-\mathrm{C}_{6} \mathrm{H}_{4}\left(\mathrm{CH}_{2} \mathrm{mMe}_{2}{ }_{2}^{+}\right]\left[\mathrm{BF}_{4}{ }^{-}\right] 2\right.$, , $3134,3153,3178 \mathrm{~cm}^{-1}$ for $\left[\mathrm{m}-\mathrm{C}_{6} \mathrm{H}_{4}\left(\mathrm{CH}_{2} \mathrm{lmMe}\right)_{2}{ }^{+}\right]\left[\mathrm{NTF}_{2}{ }^{-}\right]$, (Figure 6). In this region, the vibrational bands at higher wavenumbers can be referred to $\mathrm{C}(4,5)-\mathrm{H}$ stretching modes, whereas those at lower wavenumbers can be assigned to the $\mathrm{C}(2)-\mathrm{H}$ stretching modes. 


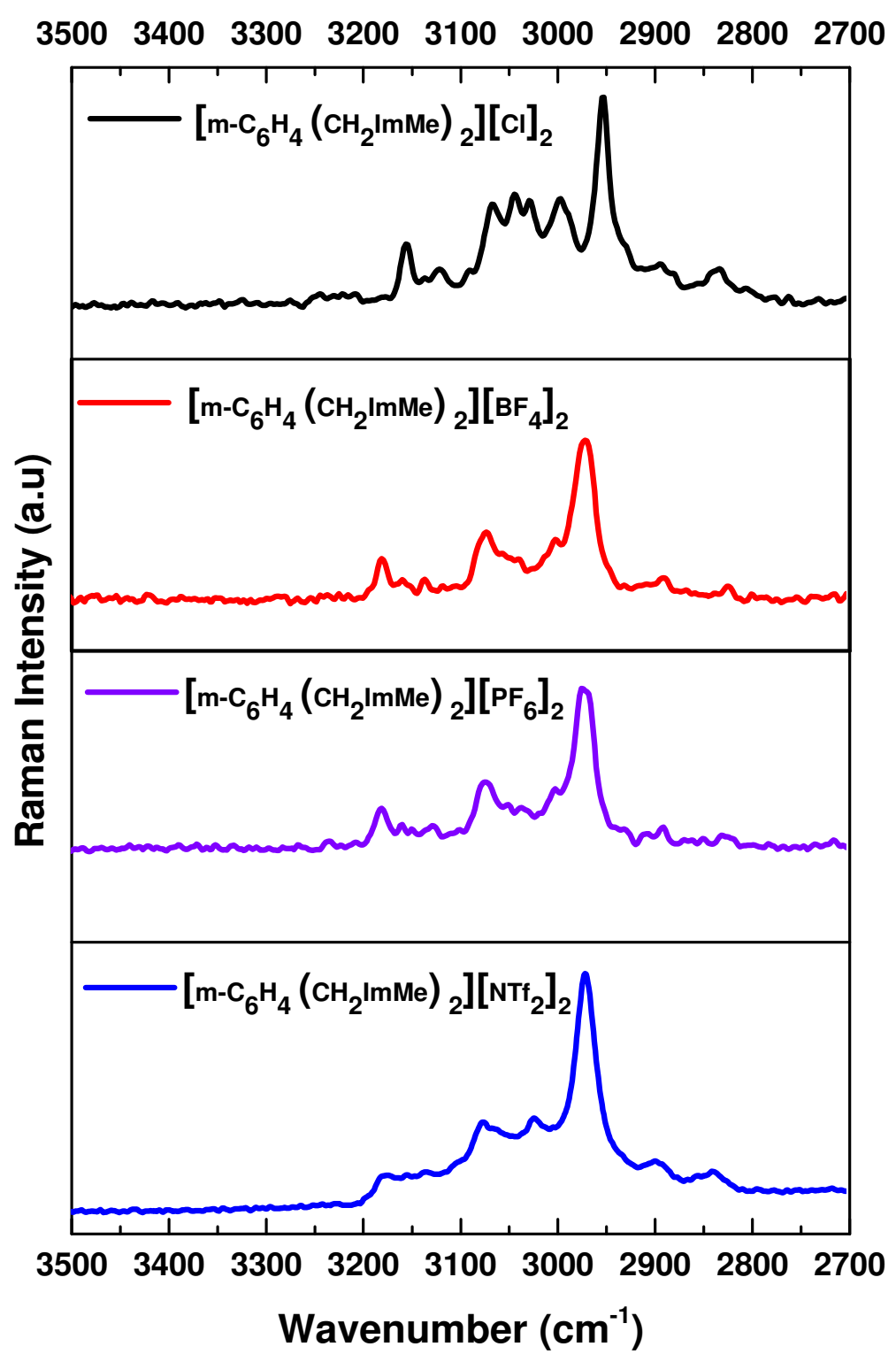

Figure 8. Raman spectra of the four dicationic ILs in the frequency range $3500-$ $2700 \mathrm{~cm}^{-1}$. 
Table 5. Observed FT-RAMAN bands and their assignment of 4 dicationic ILs at room temperature. $(\mathrm{vw}=$ Very weak; $\mathrm{w}=$ weak; $\mathrm{m}=$ medium, $\mathrm{s}=$ strong; $\mathrm{sh}=$ shoulder; $v=$ Str = stretch; $\delta=$ deformation; bend = bending deformation; $\omega=$ wagging; $\rho=$ rocking; $\mathrm{T}=$ torsion, $\mathrm{s}=$ symmetric; as = antisymmetric).

\begin{tabular}{|c|c|c|c|c|c|}
\hline \multicolumn{4}{|c|}{$\left[\mathrm{m}-\mathrm{C}_{6} \mathrm{H}_{4}\left(\mathrm{CH}_{2} \mathrm{ImMe}\right)_{2}\right]$} & \multirow{2}{*}{ Vibrational assignment } & \multirow{2}{*}{ Refs } \\
\hline$[\mathrm{Cl}]_{2}$ & {$\left[\mathrm{PF}_{6}\right]_{2}$} & {$\left[\mathrm{BF}_{4}\right]_{2}$} & {$\left[\mathrm{NTf}_{2}\right]_{2}$} & & \\
\hline & & & & Range: $3500-2700 \mathrm{~cm}^{-1}$ & \\
\hline & $3179(w)$ & $3179(w)$ & $3178(\mathrm{vw})$ & H-C-C-H asymmetric stretch, $\mathrm{V}_{\text {as }}(\mathrm{H}-\mathrm{C}(4)), \mathrm{V}_{\text {as }}(\mathrm{H}-\mathrm{C}(5))$ & {$[44] /[45] /[55] /[69] /[70]$} \\
\hline $3152(w)$ & $3158(v w)$ & $3158(\mathrm{vw})$ & $3153(v w)$ & $\mathrm{H}-\mathrm{C}-\mathrm{C}-\mathrm{H}$ asymmetric stretch & {$[52] /[63] /[60] /[69] /[70]$} \\
\hline $3119(v w)$ & $3127(v w)$ & $3135(\mathrm{vw})$ & $3134(v w)$ & $\mathrm{H}-\mathrm{C}-\mathrm{C}-\mathrm{H}$ asymmetric stretch, $\mathrm{V}_{\text {as }}(\mathrm{H}-\mathrm{C}(2))$ & {$[52] /[55] /[69] /[70]$} \\
\hline $3065(w)$ & $3071(w)$ & $3071(w)$ & $3075(w)$ & C-H stretching & {$[65] /[66] /[68]$} \\
\hline $3043(v w)$ & & & & C-H stretching & {$[45] /[54] /[65] /[70]$} \\
\hline $3027(\mathrm{vw})$ & & $3031(\mathrm{vw})$ & $3022(\mathrm{vw})$ & C-H stretching & {$[54] /[68] /[69]$} \\
\hline \multirow{2}{*}{$2994(w)$} & 2999 (sh) & 2999 (sh) & & $(\mathrm{N}) \mathrm{CH}_{3}$ asymmetric stretch & {$[54] /[61] /[69] /[70]$} \\
\hline & $2971(\mathrm{~m})$ & $2969(\mathrm{~m})$ & $2969(\mathrm{~m})$ & $(\mathrm{N}) \mathrm{CH}_{3}$ asymmetric stretch, $\quad v_{\text {as }}\left(\mathrm{CH}_{3}\right)$ & {$[61] /[66] /[68]$} \\
\hline $2949(\mathrm{~m})$ & & 2928 (vw) & & $(\mathrm{N}) \mathrm{CH}_{2},(\mathrm{~N}) \mathrm{CH}_{3}$ symmetric stretch & {$[53] /[60] /[42]$} \\
\hline $2890(\mathrm{vw})$ & $2890(\mathrm{vw})$ & $2890(\mathrm{vw})$ & $2897(\mathrm{vw})$ & $(\mathrm{N}) \mathrm{CH}_{2},(\mathrm{~N}) \mathrm{CH}_{3}$ symmetric stretch & {$[44] /[70]$} \\
\hline \multirow[t]{3}{*}{$2830(\mathrm{vw})$} & $2828(\mathrm{vw})$ & & $2838(w)$ & $(\mathrm{N}) \mathrm{CH}_{2},(\mathrm{~N}) \mathrm{CH}_{3}$ symmetric stretch & {$[54] /[43] /[69]$} \\
\hline & & $2822(\mathrm{vw})$ & & $\mathrm{v}_{\mathrm{s}}\left(\mathrm{CH}_{3}\right),(\mathrm{N}) \mathrm{CH}_{2},(\mathrm{~N}) \mathrm{CH}_{3}$ sym stretch & {$[58] /[21] /[69] /[70]$} \\
\hline & & & & Range: $1700-1000 \mathrm{~cm}^{-1}$ & \\
\hline \multirow[t]{2}{*}{$1610(\mathrm{~s})$} & $1616(v w)$ & $1616(\mathrm{vw})$ & $1615(v w)$ & Phenyl ring: $\mathrm{v} \mathrm{C}=\mathrm{C}$ & {$[48] /[49] /[50] /[51]$} \\
\hline & $1596(\mathrm{~m})$ & $1597(\mathrm{~m})$ & $1596(\mathrm{~m})$ & Phenyl ring: $\mathrm{v} \mathrm{C}=\mathrm{C}$ & {$[48] /[49] /[50] /[51]$} \\
\hline $1572(\mathrm{vw})$ & $1575(\mathrm{vw})$ & $1575(\mathrm{vw})$ & 1574(vw) & Phenyl ring $\vee \mathrm{C}=\mathrm{C},(\mathrm{N}) \mathrm{CH}_{2}$ str & $\begin{array}{l}{[41] /[52][48] /[49] /} \\
{[50] /[51]}\end{array}$ \\
\hline $1525(w)$ & & & & Phenyl ring: $v \mathrm{C}=\mathrm{C}, \operatorname{Im}$ ring $\vee(\mathrm{N}=\mathrm{C})$ & {$[41] /[52]$} \\
\hline $1455(w)$ & 1457(w) & $1457(w)$ & $1457(w)$ & Phenyl ring $\vee \mathrm{C}=\mathrm{C},(\mathrm{N}) \mathrm{CH}_{3}$ str, $\mathrm{C}-\mathrm{H}$ deformation & {$[48] /[49] /[50] /[51]$} \\
\hline $1434(\mathrm{vw})$ & $1429(w)$ & $1429(w)$ & 1430 (sh) & Im ring:C-N/C=N stretching band, $\delta\left(\mathrm{CH}_{2}\right)$ & {$[42] /[48] /[61] /[66]$} \\
\hline $1417(w)$ & $1415(\mathrm{~m})$ & $1415(\mathrm{~m})$ & $1418(w)$ & $\begin{array}{l}\text { Im ring:C- } \mathrm{N} / \mathrm{C}=\mathrm{N} \text { stretching band, }(\mathrm{N}) \mathrm{CH}_{2} \text { str }, \mathrm{C}-\mathrm{H} \\
\text { deformation }\end{array}$ & {$[46] /[53] /[51]$} \\
\hline \multirow[t]{2}{*}{$1384(\mathrm{vw})$} & $1387(w)$ & $1387(w)$ & $1390(w)$ & Imidazole ring:C-N/C=N stretch band & {$[43] /[46] /[53] /[66]$} \\
\hline & & & $1352(\mathrm{sh})$ & $\begin{array}{l}\text { Imidazole ring : } \mathrm{C}-\mathrm{N} / \mathrm{C}=\mathrm{N} \text { stretching band, Trans }\left[\mathrm{NTf}_{2}\right] \text { : } \\
\mathrm{vas}_{\mathrm{as}}\left(\mathrm{SO}_{2}\right),(\mathrm{N}) \mathrm{CH}_{2} \text { str }\end{array}$ & {$[48] /[49] /[50] /[51] /[25]$} \\
\hline $1334(v w)$ & $1332(w)$ & $1334(w)$ & $1335(\mathrm{~m})$ & $\begin{array}{l}\text { Imidazole ring:C-N/C=N stretch band, Trans }\left[\mathrm{NTf}_{2}\right]: \mathrm{vas}_{\mathrm{as}} \\
\mathrm{op}_{\left(\mathrm{S} \mathrm{S}_{2}\right)}\end{array}$ & {$[42] /[43] /[53] /[61] /[25]$} \\
\hline \multirow[t]{3}{*}{$1288(\mathrm{~m})$} & $1289(\mathrm{vw})$ & $1291(\mathrm{vw})$ & & Phenyl ring: C-C stretching & {$[51] /[61] /[69]$} \\
\hline & $1251(\mathrm{~m})$ & $1249(w)$ & $1244(\mathrm{~m})$ & Phenyl ring: $\mathrm{C}-\mathrm{C}$ stretching/ Trans $\left[\mathrm{NTf}_{2}\right]: \mathrm{v}_{\mathrm{s}}\left(\mathrm{CF}_{3}\right)$ & $\begin{array}{l}{[48] /[49] /} \\
{[50] /[51] /[25] /[70]}\end{array}$ \\
\hline & & $1205(\mathrm{vw})$ & & $\mathrm{BF}_{4}$ asym str, Phenyl ring: $\mathrm{C}-\mathrm{C}$ stretching & {$[53] /[63]$} \\
\hline \multirow[t]{4}{*}{$1199(\mathrm{~m})$} & $1190(v w)$ & $1190(v w)$ & $1195(\mathrm{vw})$ & $\begin{array}{l}\text { Phenyl ring: C-C stretching, C- C-H i p bend, C- C- H ip } \\
\text { bend }\end{array}$ & {$[51] /[67] /[69]$} \\
\hline & $1168(v w)$ & $1169(\mathrm{vw})$ & $1178(\mathrm{vw})$ & $\delta \mathrm{CH}, \mathrm{CH}_{3} \mathrm{~N}$ & {$[46] /[51] /[53] /[69]$} \\
\hline & & & $1135(\mathrm{~m})$ & Trans $\left[\mathrm{NTf}_{2}\right]:: \mathrm{v}_{\mathrm{s}, \mathrm{ip}}\left(\mathrm{SO}_{2}\right)$ & {$[25] /[42] /[55]$} \\
\hline & $1110(w)$ & $1112(\mathrm{w})$ & $1106(\mathrm{vw})$ & $\delta \mathrm{CH}$, ring $\mathrm{HCCH}$ sym bend & {$[46] /[53] /[61]$} \\
\hline \multirow[t]{4}{*}{$1023(\mathrm{~m})$} & $1025(\mathrm{~m})$ & $1025(\mathrm{~m})$ & $1023(\mathrm{~m})$ & $\delta \mathrm{CC}, \delta \mathrm{CH}, \mathrm{BF}_{4}$ asym str, $\mathrm{v}_{\text {as }}(\mathrm{BF}(4)), \mathrm{v}_{\text {as }}(\mathrm{BF}(2))$ & {$[53] /[61] /[58]$} \\
\hline & 1006(sh) & $1008(\mathrm{sh})$ & $1003(\mathrm{sh})$ & C-C ring stretch & {$[51] /[67]$} \\
\hline & & & & Range: $1000-45 \mathrm{~cm}^{-1}$ & \\
\hline & $931(\mathrm{vw})$ & $932(\mathrm{vw})$ & & $(\mathrm{N}) \mathrm{CH}_{2}, \mathrm{BF}_{4}$ asym str & {$[21] /[53]$} \\
\hline \multirow[t]{3}{*}{$882(\mathrm{vw})$} & $876(v w)$ & $882(\mathrm{vw})$ & & $\rho\left(\mathrm{CH}_{2}\right), \mathrm{NC}(\mathrm{H}) \mathrm{N}$ bend/CCH bend & {$[52] /[61]$} \\
\hline & $864(v w)$ & & & $\mathrm{PF}_{6}$ asym str & {$[46] /[25]$} \\
\hline & & $855(\mathrm{vw})$ & $856(\mathrm{vw})$ & $\mathrm{NC}(\mathrm{H}) \mathrm{N}$ bend & {$[44] /[45] /[46] /[47]$} \\
\hline $836(\mathrm{~m})$ & & $834(\mathrm{vw})$ & & Ring $\mathrm{HCCH}$ asym bend & {$[53] /[66]$} \\
\hline \multirow[t]{2}{*}{$815(\mathrm{sh})$} & $817(\mathrm{vw})$ & $818(\mathrm{vw})$ & & $\mathrm{HCCH}$ sym bend & {$[52] /[66]$} \\
\hline & & & 795 (sh) & $\mathrm{v}_{\mathrm{s}}(\mathrm{CS})$ & [25] \\
\hline $782(w)$ & $784(w)$ & $786(w)$ & & $\mathrm{V}_{\mathrm{s}} \mathrm{CC}, \mathrm{HCCH}$ sym bend & {$[52] /[60] /[66]$} \\
\hline 767(sh) & & $766(v w)$ & 766 (sh) & $\mathrm{v}_{\mathrm{s}}(\mathrm{SNS}),(\mathrm{N}) \mathrm{CH}_{2}$ str, $\mathrm{NCH}_{3}, \delta \mathrm{CC}, \mathrm{C}=\mathrm{C}-\mathrm{H}$, ring $\mathrm{HCCH}$ & {$[43] /[45] /[46] /[47]$} \\
\hline
\end{tabular}




\begin{tabular}{|c|c|c|c|c|c|}
\hline & & & & asym bend & \\
\hline & $742(\mathrm{~s})$ & $743(\mathrm{~s})$ & 741 (s) & $v\left(P F_{6}\right), B_{4}$ scissors , $v_{s}\left(B_{4}\right)$, Trans $\left[\mathrm{NTf}_{2}\right]: \delta_{s}\left(\mathrm{CF}_{3}\right)$ & $\begin{array}{l}{[25] /[44] /[45] /[46] /} \\
{[47] /[53] /[70]}\end{array}$ \\
\hline $711(v w)$ & $700(v w)$ & $701(\mathrm{vw})$ & $696(\mathrm{vw})$ & $\mathrm{C}=\mathrm{C}-\mathrm{H}, \mathrm{H}-\mathrm{C}-\mathrm{C}-\mathrm{H}$ & {$[21] /[49]$} \\
\hline $652(v w)$ & $667(\mathrm{vw})$ & $668(\mathrm{vw})$ & $659(w)$ & $\delta \mathrm{CC}, \mathrm{C}=\mathrm{C}-\mathrm{H}, \mathrm{CH}_{2}(\mathrm{~N}) / \mathrm{CH}_{3}(\mathrm{~N}) \mathrm{CN} \mathrm{Str}$ & {$[48] /[49] /[50] /[51] /[61]$} \\
\hline $632(w)$ & $641(w)$ & $642(w)$ & & $\delta \mathrm{CC},(\mathrm{N}-\mathrm{C}),(\mathrm{N}) \mathrm{CH}_{2} \mathrm{str}, \quad \vee \mathrm{N}-\mathrm{CH}_{3}$ & {$[48] /[63]$} \\
\hline \multirow[t]{5}{*}{$616(w)$} & $618(w)$ & $618(w)$ & $620(w)$ & $\begin{array}{l}\left.\delta \mathrm{CC}, \mathrm{NCH}_{3} \text { Trans-[NTf }\right]: \delta S N S, \delta \text { op as }\left(\mathrm{SO}_{2}\right), \text { Phenyl } \\
\text { ring } \vee \mathrm{C}=\mathrm{C}\end{array}$ & {$[44] /[45] /[46] /[47] /[25]$} \\
\hline & & & $591(w)$ & Trans-[NTf $\left.\mathrm{NT}_{2}\right]: \delta_{\mathrm{as}}\left(\mathrm{CF}_{3}\right), \delta$ ip as $\left(\mathrm{SO}_{2}\right), \delta_{\mathrm{s}}\left(\mathrm{NSO}_{2}\right)$ & $\begin{array}{l}{[25] /[42] /[44] /[45] /[46] /} \\
{[47]}\end{array}$ \\
\hline & & & $552(w)$ & Trans-[NTf $\left.{ }_{2}\right]: \delta_{s}\left(\mathrm{SO}_{2}\right)$ & {$[44] /[25]$} \\
\hline & $503(\mathrm{vw})$ & 504(vw) & $507(\mathrm{vw})$ & $\mathrm{BF}_{4}$ scissors, $\delta\left(\mathrm{BF}_{4}\right), \mathrm{SO}_{2}$ sym bending & {$[52] /[[53] /[63] /[25]$} \\
\hline & $470(\mathrm{vw})$ & $470(\mathrm{vw})$ & & $\vee\left(\mathrm{PF}_{6}\right), \quad \delta\left(\mathrm{BF}_{4}\right), \quad \vee(\mathrm{BF})$ & {$[25] /[52] /[55] /[63]$} \\
\hline \multirow[t]{5}{*}{$412(w)$} & & & $404(v w)$ & $(\mathrm{N}) \mathrm{CH}_{2}$ str, $\mathrm{NCH}_{3}$, Trans-[NTf 2$]: \omega\left(\mathrm{SO}_{2}\right)$ & {$[44] /[45] /[46] /[47] /[25]$} \\
\hline & $391(\mathrm{vw})$ & $391(v w)$ & $399(\mathrm{~m})$ & $\rho\left(\mathrm{CH}_{2}\right),(\mathrm{N}) \mathrm{CH}_{2}$ str, Trans-[NTf $]: \omega\left(\mathrm{SO}_{2}\right)$ & {$[44] /[45] /[46] /[47] /[25]$} \\
\hline & & $351(\mathrm{vw})$ & & $\delta \mathrm{NCH}_{3}, \mathrm{BF}_{4}$ scissors, $\delta\left(\mathrm{BF}_{4}\right), \mathrm{CC}$ & {$[53] /[63] /[64] /[65] /[25]$} \\
\hline & & & 340 (sh) & $\delta \mathrm{NCH}_{3}$, Trans-[NTf $]: \tau\left(\mathrm{SO}_{2}\right)$ & {$[44] /[45] /[46] /[47] /[25]$} \\
\hline & & & $326(\mathrm{~m})$ & $\rho\left(\mathrm{SO}_{2}\right)$ & {$[44] /[45] /[46] /[47] /[25]$} \\
\hline \multirow[t]{2}{*}{$319(w)$} & $313(\mathrm{~m})$ & $313(\mathrm{~m})$ & $313(\mathrm{~m})$ & CN stretch , SC Str Trans-[NTf 2$]: \rho\left(\mathrm{SO}_{2}\right), \rho\left(\mathrm{CF}_{3}\right)$ & {$[44] /[45] /[46] /[47] /[25]$} \\
\hline & 282(vw) & $282(v w)$ & $282(\mathrm{~m}) / 288(\mathrm{sh})$ & $\rho\left(\mathrm{CH}_{2}\right), \mathrm{CN}$ stretch, Trans-[NTf $\left.\mathrm{NT}_{2}\right] \rho \mathrm{CF}_{3}, \mathrm{vas}(\mathrm{CS})$ & {$[45] /[46] /[55]$} \\
\hline \multirow[t]{2}{*}{$248(v w)$} & $240(v w)$ & $242(v w)$ & & $\rho\left(\mathrm{CH}_{2}\right), \quad \gamma \mathrm{N}-\mathrm{CH}_{3}$ & $[21]] /[53]$ \\
\hline & $221(v w)$ & $219(\mathrm{vw})$ & $208(v w)$ & $\mathrm{T}(\mathrm{N}-\mathrm{C}) / \rho\left(\mathrm{CH}_{2}\right), \mathrm{NCH}_{3}$ & {$[41] /[55] /[60]$} \\
\hline $190(w)$ & $185(w)$ & $186(w)$ & $172(w)$ & Intermolecular vibration, $\omega(\mathrm{N}-\mathrm{C}), \mathrm{T}(\mathrm{N}-\mathrm{C}) / \mathrm{\rho}\left(\mathrm{CH}_{2}\right)$ & {$[41] /[55] /[60] /[62]$} \\
\hline 90(sh) & $95(\mathrm{sh})$ & 99(sh) & & Intermolecular vibration & [62] \\
\hline 90 (sh) & 95 (sh) & 99(sh) & & Intermolecular vibration & [62] \\
\hline 90(sh) & 95 (sh) & 99(sh) & & Intermolecular vibration & [62] \\
\hline $61(\mathrm{sh})$ & 69 (sh) & 70 (sh) & $72(s)$ & Intermolecular vibration & [62] \\
\hline
\end{tabular}

\subsection{COMPUTATIONAL INVESTIGATION OF THE STRUCTURE ANIONS-CATION}
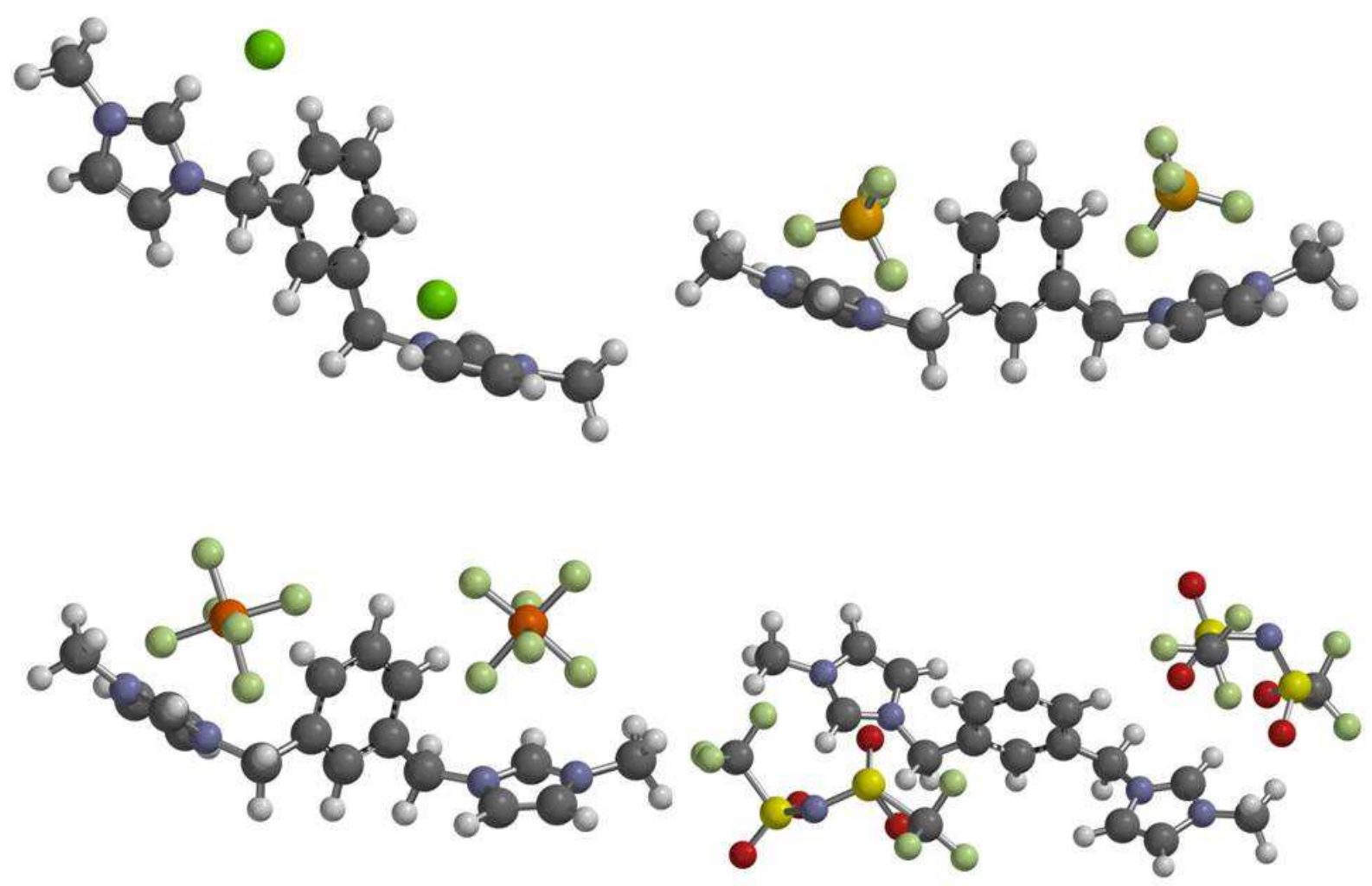
Figure 9. Schematics of the optimized structures of the four ILs with different anions (top-left: Cl; top-right: $\mathrm{BF}_{4}$; bottom-left: $\mathrm{PF}_{6}$; bottom-right: $\mathrm{NTf}_{2}$ ).

The optimized structures of the four ionic couples of $m$-xylene with $2 \mathrm{Cl}^{-}, 2 \mathrm{BF}_{4}^{-}, 2$ $\mathrm{PF}_{6}{ }^{-}$or $2 \mathrm{NTf}_{2}{ }^{-}$anions were obtained by DFT calculations using the $6-31 \mathrm{G}^{\star *}$ basis set and the B3LYP theory. Different starting geometries were investigated. For all the four possible anions, the cation preserves its structure close to that found for conformer A, reported in Section 4.1 (see Figure 9). Moreover, in all cases the two anions prefer to reside both in the same half plane were the benzene ring is placed, in positions close to the imidazolium C13 and C15 carbon atoms (see Figure 2) and the attached $\mathrm{H}$ atoms. The only exception is observed in the case of the two $\mathrm{Cl}^{-}$ anions, which prefer to displace toward the methylene groups with carbon atoms C7 and C8. In this case the distances between $\mathrm{Cl}$ and the hydrogen atoms of the imidazolium ring ( $\mathrm{H} 14$, Figure 9), of the methyl group $(\mathrm{H} 7)$ and of the benzene ring $(\mathrm{H} 1)$ are 2.027, 2.521 and $2.861 \AA$, respectively. In the case of the $\mathrm{BF}_{4}$ anions the $\mathrm{F} 2$ and $\mathrm{F} 1$ atoms (figure 2) distance from $\mathrm{H} 14$ are 2.030 and $2.091 \AA$, while for $\mathrm{PF}_{6}$ the F1 and F2 distance from H14 increases to 2.046 and 2.105 $\AA$. Finally in the case of $\mathrm{NTf}_{2}$, the closest oxygen atom has a distance of $1.929 \AA$ from $\mathrm{H} 14$. In all cases the anions reside outside the planes defined by the imidazolium rings, with increasing distance for $\mathrm{Cl}, \mathrm{BF}_{4}, \mathrm{PF}_{6}$ and $\mathrm{NTf}_{2}$. However, these results need to be compared to experimental structural data, that at present are not available, due to the lack of $X$ ray diffraction data in the solids.

\section{CONCLUSION}

Four new substituted dicationic ionic liquids based on meta-xylyl linked bis-1methylimidazolium, combined with four anions, namely dichloride $\left[\mathrm{Cl}^{-}\right]_{2}$, di(bis(trifluoromethylsulfonyl) Imide) $\left[\left(\mathrm{CF}_{3} \mathrm{SO}_{2}\right)_{2} \mathrm{~N}^{-}\right]_{2}$, di(tetrafluoroborate) $\left[\mathrm{BF}_{4}^{-}\right]_{2}$ and di(hexafluorophosphate) $\left[\mathrm{PF}_{6}{ }^{-}\right] 2$ were synthesized for the first time. ${ }^{1} \mathrm{H},{ }^{13} \mathrm{C},{ }^{19} \mathrm{~F}$ and ${ }^{31} \mathrm{P}-\mathrm{NMR}$ spectroscopies confirm the production of the desired ILs. Combined TGA/DTA measurements indicate that the thermal stability of the ILs is in the following order $\mathrm{NTf}_{2}>\mathrm{PF}_{6}>\mathrm{BF}_{4}>\mathrm{Cl}$; the latter compound is highly hygroscopic. While the $\mathrm{NTf}_{2}$ based sample is liquid at room temperature, the other three samples are solid and the melting points are in the order $\mathrm{NTf}_{2}<\mathrm{BF}_{4}<\mathrm{PF}_{6}<\mathrm{Cl}$. Moreover, the vibrational spectra of these ionic liquids were investigated by using FTIR and FT- 
RAMAN spectroscopies. Quantum chemical theory (at the DFT level) was used to calculate the possible conformers of the cation. Due to the complex structure of the cation seven conformers exists with a difference in energy of less than $5 \mathrm{~kJ} / \mathrm{mol}$. The comparison with the experimental IR spectrum suggests that at least three of them could be present in the samples. Finally a computational investigation of the interaction between anions and cation is presented.

\section{ACKNOWLEDGEMENTS}

The authors gratefully acknowledge the financial support by The Ministry of Higher Education and Scientific Research (MESRS) of Algeria in PRFU project code: B00L01UN200120180002; also, Mostefa Boumediene would like to thank Doctor Guendouzi Abdelkrim, Head of the Department of Chemistry, Faculty of Sciences, University of Saïda, Algeria for their fruitful support, Moreover; Mostefa Boumediene would like to congratulate his supervisor Mr : HADDAD, who deserve the second place in the promotion of the rank of Professor related to 41 st session of CUN results. 


\section{REFERENCES}

[1] Reichardt, C., \& Welton, T. (2011). Solvents and solvent effects in organic chemistry. John Wiley \& Sons.

[2] Cull, S. G., Holbrey, J. D., Vargas-Mora, V., Seddon, K. R., \& Lye, G. J. (2000). Room-temperature ionic liquids as replacements for organic solvents in multiphase bioprocess operations. Biotechnology and Bioengineering, 69(2), 227-233.

[3] Suarez, P. A. Z., Einloft, S., Dullius, J. E. L., De Souza, R. F., \& Dupont, J. (1998). Synthesis and physical-chemical properties of ionic liquids based on 1-n-butyl-3-methylimidazolium cation. Journal de Chimie Physique et de Physico-Chimie Biologique, 95(7), 1626-1639.

[4] Wasserscheid, P., \& Welton, T. (Eds.). (2008). Ionic liquids in synthesis. John Wiley \& Sons. [5] Anderson, J. L., Ding, J., Welton, T., \& Armstrong, D. W. (2002). Characterizing ionic liquids on the basis of multiple solvation interactions. Journal of the American Chemical Society, 124(47), 14247-14254.

[6] Poole, C. F. (2004). Chromatographic and spectroscopic methods for the determination of solvent properties of room temperature ionic liquids. Journal of chromatography $A, 1037(1-2)$, 49-82.

[7] Haddad, B., Moumene, T., Villemin, D., Lohier, J. F., \& Belarbi, E. H. (2016). Bis-methyl imidazolium methylidene bis (trifluoromethanesulfonyl) imide, crystal structure, thermal and dielectric studies. Bulletin of Materials Science, 39(3), 797-801.

[8] Huddleston, J. G., Willauer, H. D., Swatloski, R. P., Visser, A. E., \& Rogers, R. D. (1998). Room temperature ionic liquids as novel media for 'clean'liquid-liquid extraction. Chemical Communications, (16), 1765-1766.

[9] Panja, S. K., Haddad, B., \& Kiefer, J. (2018). Clusters of the Ionic Liquid 1-Hydroxyethyl-3-methylimidazolium Picrate: From Theoretical Prediction in the Gas Phase to Experimental Evidence in the Solid State. ChemPhysChem, 19(22), 3061-3068.

[10] Merouani, S., Hamdaoui, O., \& Haddad, B. (2018). Acoustic cavitation in 1-butyl-3methylimidazolium bis (triflluoromethyl-sulfonyl) imide based ionic liquid. Ultrasonics sonochemistry, 41, 143-155.

[11] Panja, S. K., Haddad, B., Debdab,M., Kiefer, J., Chaker,Y., B Bresson, S., Paolone, A. (2019). Cluster formation through hydrogen bond bridges across chloride anions in a hydroxyl-functionalized ionic liquid. ChemPhysChem. https://doi.org/10.1002/cphc.201801206

[12] Chae, H., Lee, Y. H., Yang, M., Yoon, W. J., Yoon, D. K., Jeong, K. U., ... \& Lee, M. (2019). Interesting phase behaviors and ion-conducting properties of dicationic $\mathrm{N}$-alkylimidazolium tetrafluoroborate salts. RSC Advances, 9(7), 3972-3978.

[13] Anderson, J. L., Ding, R., Ellern, A., \& Armstrong, D. W. (2005). Structure and properties of high stability geminal dicationic ionic liquids. Journal of the American Chemical Society, 127(2), 593-604.

[14] Haddad, B., Villemin, D., Belarbi, E. H., Bar, N., \& Rahmouni, M. (2014). New dicationic piperidinium hexafluorophosphate ILs, synthesis, characterization and dielectric measurements. Arabian Journal of Chemistry, 7(5), 781-787.

[15] Zhang, Z., Yang, L., Luo, S., Tian, M., Tachibana, K., \& Kamijima, K. (2007). Ionic liquids based on aliphatic tetraalkylammonium dications and TFSI anion as potential electrolytes. Journal of Power sources, 167(1), 217-222

[16] Gurung, E., Meng, D., Xue, L., Tamas, G., Lynden-Bell, R. M., \& Quitevis, E. L. (2018). Optical Kerr effect spectroscopy of CS 2 in monocationic and dicationic ionic liquids: insights into the intermolecular interactions in ionic liquids. Physical Chemistry Chemical Physics, 20(41), 26558-26569.

[17] Montalbán, M. G., Víllora, G., \& Licence, P. (2018). Ecotoxicity assessment of dicationic versus monocationic ionic liquids as a more environmentally friendly alternative. Ecotoxicology and environmental safety, 150, 129-135.

[18] Payagala, T., Huang, J., Breitbach, Z. S., Sharma, P. S., \& Armstrong, D. W. (2007). Unsymmetrical dicationic ionic liquids: manipulation of physicochemical properties using specific structural architectures. Chemistry of Materials, 19(24), 5848-5850. 
[19] Shirota, H., Mandai, T., Fukazawa, H., \& Kato, T. (2011). Comparison between dicationic and monocationic ionic liquids: liquid density, thermal properties, surface tension, and shear viscosity. Journal of Chemical \& Engineering Data, 56(5), 2453-2459.

[20] Haddad, B., Paolone, A., Villemin, D., Lohier, J. F., Drai, M., Bresson, S., \& Belarbi, E. H. (2018). Para-xylyl bis-1-methylimidazolium bis (trifluoromethanesulfonyl) imide: Synthesis, crystal structure, thermal stability, vibrational studies. Journal of Molecular Liquids, 260, 391402.

[21] Haddad, B., Paolone, A., Drai, M., Boumediene, M., Villemin, D., Belarbi, E. H., \& Abbas, O. (2019). Para-xylyl linked bis-imidazolium ionic liquids: A study of the conformers of the cation and of the anion-cation hydrogen bonding. Journal of Molecular Structure, 1175, 175184.

[22] Haddad, B., Villemin, D., \& Belarbi, E. H. (2014). Synthesis of palladium-bidentate complex and its application in Sonogashira and Suzuki coupling reactions. Chemical Papers, 68(5), 656661.

[23] Shao, Y., Molnar, L. F., Jung, Y., Kussmann, J., Ochsenfeld, C., Brown, S. T., ... \& Gill, P.M.W., and Head-Gordon, M., (2006). Advances in methods and algorithms in a modern quantum chemistry program package. Physical Chemistry Chemical Physics, 8(27), 3172-3191. [24] Hehre, W. J. (2003). A guide to molecular mechanics and quantum chemical calculations (Vol. 2). Irvine, CA: Wavefunction.

[25] Paschoal, V. H., Faria, L. F., \& Ribeiro, M. C. (2017). Vibrational Spectroscopy of Ionic Liquids. Chemical reviews, 117(10), 7053-7112.

[26] Vitucci, F.M., Trequattrini, F., Palumbo, O., Brubach, J.-B., Roy, P., Paolone. A. (2014) Infrared spectra of bis(trifluoromethanesulfonyl)imide based ionic liquids: Experiments and DFT simulations. Vibrational Spectroscopy, 74, 81-87.

[27] Capitani, F., Trequattrini, F., Palumbo, O., Paolone, A., \& Postorino, P. (2016). Phase transitions of PYR14-TFSI as a function of pressure and temperature: the competition between smaller volume and lower energy conformer. The Journal of Physical Chemistry B, 120(11), 2921-2928.

[28] Vitucci, F. M., Trequattrini, F., Palumbo, O., Brubach, J. B., Roy, P., Navarra, M. A., ... \& Paolone, A. (2014). Stabilization of different conformers of bis (trifluoromethanesulfonyl) imide anion in ammonium-based ionic liquids at low temperatures. The Journal of Physical Chemistry A, 118(38), 8758-8764.

[29] Ibrahim, H., Koorbanally, N. A., Ramjugernath, D., Bala, M. D., \& Nyamori, V. O. (2012). Synthesis and characterization of imidazolium salts bearing fluorinated anions. Zeitschrift für anorganische und allgemeine Chemie, 638(14), 2304-2309.

[30] Willans, C. E., Anderson, K. M., Paterson, M. J., Junk, P. C., Barbour, L. J., \& Steed, J. W. (2009). Bis (N-heterocyclic carbene) Dipalladium Complexes: Synthesis, Solid-State Conformational Studies and Solution Behaviour. European Journal of Inorganic Chemistry, 2009(19), 2835-2843.

[31] Maton, C., De Vos, N., \& Stevens, C. V. (2013). Ionic liquid thermal stabilities: decomposition mechanisms and analysis tools. Chemical Society Reviews, 42(13), 5963-5977.

[32] Ngo, H. L., LeCompte, K., Hargens, L., \& McEwen, A. B. (2000). Thermal properties of imidazolium ionic liquids. Thermochimica Acta, 357, 97-102.

[33] Clough, M. T., Geyer, K., Hunt, P. A., Mertes, J., \& Welton, T. (2013). Thermal decomposition of carboxylate ionic liquids: trends and mechanisms. Physical Chemistry Chemical Physics, 15(47), 20480-20495.

[34] Zhou, Z. B., Matsumoto, H., \& Tatsumi, K. (2004). Low-melting, low-viscous, hydrophobic ionic liquids: 1-alkyl (alkylether)-3-methylimidazolium perfluoroalkyltrifluoroborate. Chemistry- $A$ European Journal, 10(24), 6581-6591.

[35] Fox, D. M., Awad, W. H., Gilman, J. W., Maupin, P. H., Hugh, C., \& Trulove, P. C. (2003). Flammability, thermal stability, and phase change characteristics of several trialkylimidazolium salts. Green Chemistry, 5(6), 724-727. 
[36] Awad, W. H., Gilman, J. W., Nyden, M., Harris Jr, R. H., Sutto, T. E., Callahan, J., ... \& Fox, D. M. (2004). Thermal degradation studies of alkyl-imidazolium salts and their application in nanocomposites. Thermochimica Acta, 409(1), 3-11.

[37] MacFarlane, D. R., Meakin, P., Sun, J., Amini, N., \& Forsyth, M. (1999). Pyrrolidinium imides: a new family of molten salts and conductive plastic crystal phases. The Journal of Physical Chemistry B, 103(20), 4164-4170.

[38] Dearden, J. C. (1991). The QSAR prediction of melting point, a property of environmental relevance. Science of the total environment, 109, 59-68.

[39] Abramowitz, R., \& Yalkowsky, S. H. (1990). Melting point, boiling point, and symmetry. Pharmaceutical research, 7(9), 942-947.

[40] Holbrey, J. D., \& Rogers, R. D. (2003). Physiochemical Properties of lonic Liquids: Melting Points and Phase Diagrams in. Ionic Liquids in Synthesis vol, 1, 57-72.

[41] Malek, K., Puc, A., Schroeder, G., Rybachenko, V. I., \& Proniewicz, L. M. (2006). FT-IR and FT-Raman spectroscopies and DFT modeling of benzimidazolium salts. Chemical physics, 327(2-3), 439-451.

[42] Kiefer, J., Fries, J., \& Leipertz, A. (2007). Experimental vibrational study of imidazoliumbased ionic liquids: Raman and infrared spectra of 1-ethyl-3-methylimidazolium bis (trifluoromethylsulfonyl) imide and 1-ethyl-3-methylimidazolium ethylsulfate. Applied spectroscopy, 61(12), 1306-1311.

[43] Moschovi, A. M., Ntais, S., Dracopoulos, V., \& Nikolakis, V. (2012). Vibrational

spectroscopic study of the protic ionic liquid 1-H-3-methylimidazolium bis

(trifluoromethanesulfonyl) imide. Vibrational Spectroscopy, 63, 350-359.

[44] Moumene, T., Belarbi, E. H., Haddad, B., Villemin, D., Abbas, O., Khelifa, B., \& Bresson, S.(2014). Vibrational spectroscopic study of ionic liquids: Comparison between monocationic and dicationic imidazolium ionic liquids. Journal of Molecular Structure, 1065, 86-92.

[45] Drai, M., Mostefai, A., Paolone, A., Haddad, B., Belarbi, E., Villemin, D. ...\& Rahmouni, M. (2017). Synthesis, experimental and theoretical vibrational studies of 1-methyl and 1, 2dimethyl, 3-Propylimidazolium bis (trifluoromethanesulfonyl) imide. Journal of Chemical Sciences, 129(6), 707-719.

[46] Talaty, E. R., Raja, S., Storhaug, V. J., Dölle, A., \& Carper, W. R. (2004). Raman and infrared spectra and ab initio calculations of C2-4MIM imidazolium hexafluorophosphate ionic liquids. The Journal of Physical Chemistry B, 108(35), 13177-13184.

[47] Haddad, B., Paolone, A., Villemin, D., Taqiyeddine, M., Belarbi, E. H., Bresson, S., \& Kiefer, J. (2017). Synthesis, conductivity, and vibrational spectroscopy of tetraphenylphosphonium bis (trifluoromethanesulfonyl) imide. Journal of Molecular Structure, 1146, 203-212

[48] Güllüoğlu, M. T., Erdogdu, Y., Karpagam, J., Sundaraganesan, N., \& Yurdakul, Ş. (2011). DFT, FT-Raman, FT-IR and FT-NMR studies of 4-phenylimidazole. Journal of Molecular Structure, 990(1), 14-20.

[49] Sudha, S., Karabacak, M., Kurt, M., Cinar, M., \& Sundaraganesan, N. (2011). Molecular structure, vibrational spectroscopic, first-order hyperpolarizability and HOMO, LUMO studies of 2-aminobenzimidazole. Spectrochimica Acta Part A: Molecular and Biomolecular Spectroscopy, 84(1), 184-195.

[50] Cui, S., Wang, T., \& Hu, X. (2014). Synthesis, characterization, and DFT studies of a new chiral ionic liquid from (S)-1-phenylethylamine. Spectrochimica Acta Part A: Molecular and Biomolecular Spectroscopy, 133, 778-784.

[51] Erdogdu, Y., Güllüoğlu, M. T., Yurdakul, S., \& Dereli, Ö. (2012). DFT simulations, FT-IR, FT-Raman, and FT-NMR spectra of 4-(4-chlorophenyl)-1H-imidazole molecules. Optics and Spectroscopy, 113(1), 23-32.

[52] Noack, K., Schulz, P. S., Paape, N., Kiefer, J., Wasserscheid, P., \& Leipertz, A. (2010). The role of the $\mathrm{C} 2$ position in interionic interactions of imidazolium based ionic liquids: a vibrational and NMR spectroscopic study. Physical Chemistry Chemical Physics, 12(42), 14153-14161. 
[53] Heimer, N. E., Del Sesto, R. E., Meng, Z., Wilkes, J. S., \& Carper, W. R. (2006). Vibrational spectra of imidazolium tetrafluoroborate ionic liquids. Journal of molecular liquids, 124(1-3), 84-95.

[54] Chaker, Y., llikti, H., Debdab, M., Moumene, T., Belarbi, E. H., Wadouachi, A. ... \& Bresson, S. (2016). Synthesis and characterization of 1-(hydroxyethyl)-3-methylimidazolium sulfate and chloride ionic liquids. Journal of Molecular Structure, 1113, 182-190.

[55] Moumene, T., Belarbi, E. H., Haddad, B., Villemin, D., Abbas, O., Khelifa, B., \& Bresson, S. (2015). Study of imidazolium dicationic ionic liquids by Raman and FTIR spectroscopies: The effect of the nature of the anion. Journal of Molecular Structure, 1083, 179-186.

[56] Talebi, M., Patil, R. A., Sidisky, L. M., Berthod, A., \& Armstrong, D. W. (2017). Branched chain dicationic ionic liquids for fatty acid methyl ester assessment by gas chromatography. Analytical and bioanalytical chemistry, 1-11.

[57] Shirini, F., Khaligh, N. G., \& Akbari-Dadamahaleh, S. (2012). Preparation, characterization and use of 1,3-disulfonic acid imidazolium hydrogen sulfate as an efficient, halogen-free and reusable ionic liquid catalyst for the trimethylsilyl protection of hydroxyl groups and deprotection of the obtained trimethylsilanes. Journal of Molecular Catalysis A: Chemical, 365, 15-23.

[58] Katsyuba, S. A., Dyson, P. J., Vandyukova, E. E., Chernova, A. V., \& Vidiš, A. (2004). Molecular Structure, Vibrational Spectra, and Hydrogen Bonding of the lonic Liquid 1-Ethyl-3methyl-1H-imidazolium Tetrafluoroborate. Helvetica Chimica Acta, 87(10), 2556-2565.

[59] Socrates, G. (2004). Infrared and Raman characteristic group frequencies: tables and charts. John Wiley \& Sons.

[60] Kadari, M., Belarbi, E. H., Moumene, T., Bresson, S., Haddad, B., Abbas, O., \& Khelifa, B. (2017). Comparative study between 1-Propyl-3-methylimidazolium bromide and trimethylene bismethylimidazolium bromide ionic liquids by FTIR/ATR and FT-RAMAN spectroscopies. Journal of Molecular Structure, 1143, 91-99

[61] Moumene, T., Belarbi, E. H., Haddad, B., Villemin, D., Abbas, O., Khelifa, B., \& Bresson, S. (2016). Vibrational spectroscopic study of imidazolium dicationic ionic liquids: effect of cation alkyl chain length. Journal of Applied Spectroscopy, 83(2), 165-171.

[62] Penna, T. C., Faria, L. F., Matos, J. R., \& Ribeiro, M. C. (2013). Pressure and temperature effects on intermolecular vibrational dynamics of ionic liquids. The Journal of chemical physics, 138(10), 104503.

[63] Katsyuba, S. A., Dyson, P. J., Vandyukova, E. E., Chernova, A. V., \& Vidiš, A. (2004). Molecular Structure, Vibrational Spectra, and Hydrogen Bonding of the lonic Liquid 1-Ethyl-3methyl-1H-imidazolium Tetrafluoroborate. Helvetica Chimica Acta, 87(10), 2556-2565.

[64] Panja, S. K., Boumediene, H., Drai, M., Villemin, D., \& Bresson, S. (2018). Probing effect of weak $\mathrm{H}$-bonding on conformational change in ionic liquid: Experimental and DFT studies. Journal of Molecular Liquids, 266, 727-732.

[65]Haddad, B., Kiefer, J., Brahim, H., Belarbi, E. H., Villemin, D., Bresson, S...., \& Palumbo, O. (2018). Effects of C (2) methylation on thermal behavior and interionic interactions in imidazolium-based ionic liquids with highly symmetric anions. Applied Sciences, 8(7), 1043.

[66] Sharma, S. K., Misra, A. K., \& Sharma, B. (2005). Portable remote Raman system for monitoring hydrocarbon, gas hydrates and explosives in the environment. Spectrochimica Acta Part A: Molecular and Biomolecular Spectroscopy, 61(10), 2404-2412.

[67] Steinert, R., Bettermann, H., \& Kleinermanns, K. (1997). Identification of xylene isomers in high-pressure liquid chromatography eluates by Raman spectroscopy. Applied spectroscopy, 51(11), 1644-1647.

[68] Haddad, B., Mokhtar, D., Goussem, M., Belarbi, E. H., Villemin, D., Bresson, S., ... \& Kiefer, J. (2017). Influence of methyl and propyl groups on the vibrational spectra of two imidazolium ionic liquids and their non-ionic precursors. Journal of Molecular Structure, 1134, 582-590.

[69] Kausteklis, J., Aleksa, V., Iramain, M. A., \& Brandán, S. A. (2018). Effect of cation-anion interactions on the structural and vibrational properties of 1-buthyl-3-methyl imidazolium nitrate ionic liquid. Journal of Molecular Structure, 1164, 563-576. 
[70] Kausteklis, J., Aleksa, V., Iramain, M. A., \& Brandán, S. A. (2019). DFT and vibrational spectroscopy study of 1-butyl-3-methylimidazolium trifluoromethanesulfonate ionic liquid. Journal of Molecular Structure, 1175, 663-676. 


\section{Graphical Abstract.}

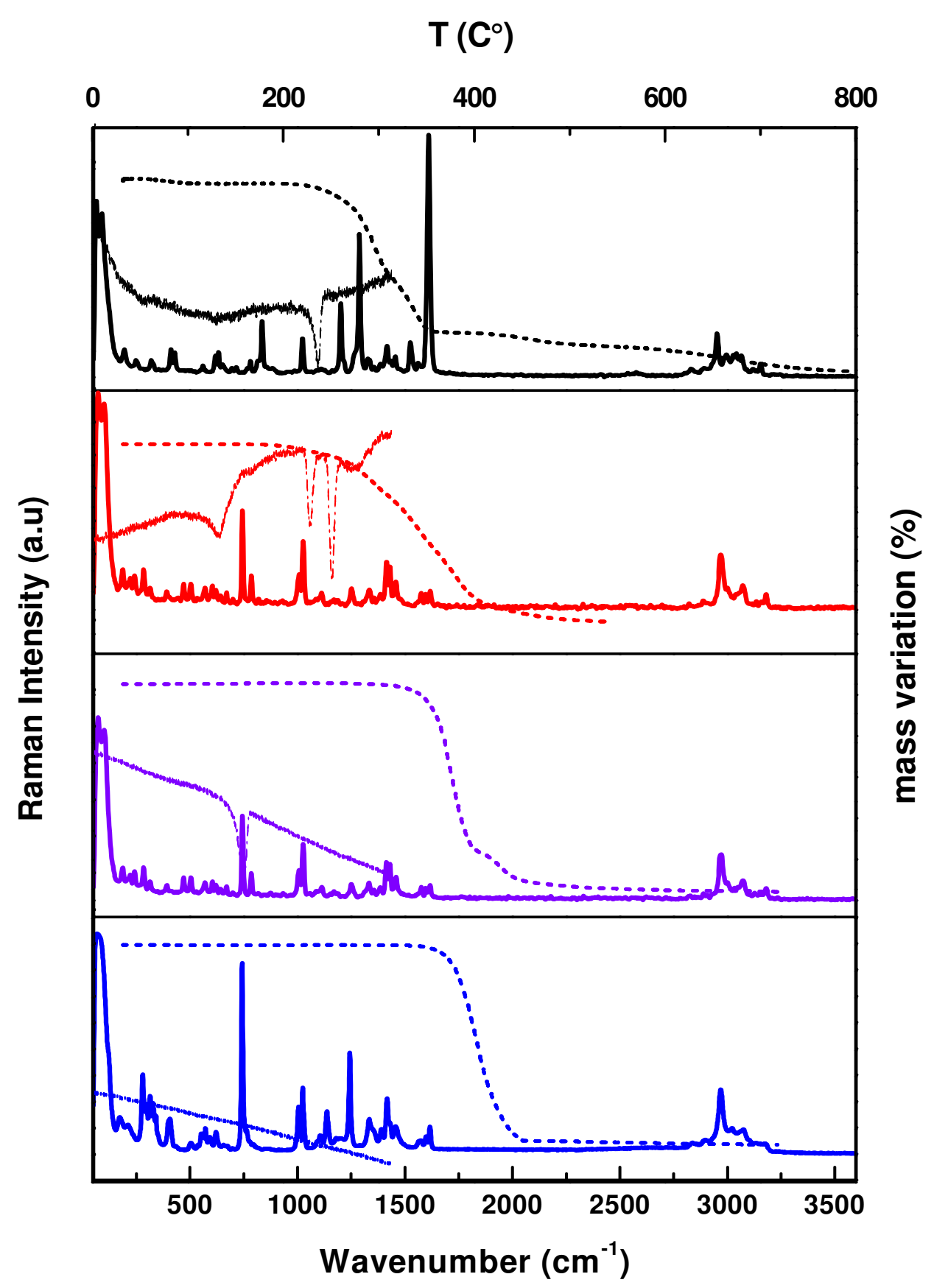

